\title{
Influence of Hudson Bay on the Carbon Dynamics of a Hudson Bay Lowlands Coastal Site
}

\begin{tabular}{|r|l|}
\hline Journal: & Arctic Science \\
\hline Manuscript ID & AS-2015-0026.R3 \\
\hline Manuscript Type: & Article \\
\hline Date Submitted by the Author: & $05-$ May-2016 \\
\hline Complete List of Authors: & $\begin{array}{l}\text { Delidjakova, Kristina; York University, Geography } \\
\text { Bello, Richard; York University, Geography } \\
\text { Higuchi, Kaz; York University, Environmental Studies } \\
\text { Pokharel, Bipin; York University, Geography }\end{array}$ \\
\hline Keyword: & photosynthesis, respiration, advection, eddy covariance, peatlands \\
\hline & \multicolumn{2}{|l}{} \\
\hline
\end{tabular}

\section{SCHOLARONE \\ Manuscripts}




\section{Influence of Hudson Bay on the Carbon Dynamics of a Hudson Bay Lowlands Coastal Site}

By Kristina K. Delidjakova ${ }^{1}$, Richard L. Bello ${ }^{1 *}$, Kaz Higuchi $^{2}$, Bipin Pokharel $^{1}$

${ }^{1}$ Department of Geography, York University, Toronto, Ontario, Canada; ${ }^{2}$ Faculty of Environmental Studies, York University Toronto, Ontario, Canada

*Corresponding Author:

Richard Bello

Department of Geography, York University,

Toronto, Ontario, M3J 1P3

Canada

Tel.: 416-736-5107 x22561

Fax: 416-736-5988

bello@yorku.ca

\section{Original Research}




\section{Abstract}

Eddy Covariance (EC) estimates of Net Ecosystem Exchange (NEE) and the surface energy balance were gathered from an elevated peat plateau within the Hudson Bay Lowlands

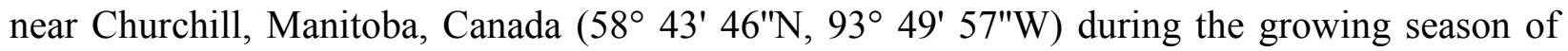
2007. Data were segregated into onshore and offshore wind regimes to assess the advective influence of the generally cold and moist Hudson Bay air masses compared to generally warm and dry air masses of non-marine origin. Monthly average net ecosystem exchange (NEE) ranged from an uptake of $0.2 \mu \mathrm{mol} / \mathrm{m}^{2} / \mathrm{s}$ in September to $5.6 \mu \mathrm{mol} / \mathrm{m}^{2} / \mathrm{s}$ in July. Over the growing season, onshore winds from Hudson Bay contributed to an average $4.2^{\circ} \mathrm{C}$ reduction in air temperature and an NEE increase of $27 \%$. When normalized with respect to sunlight receipt, the ratio of gross primary production to photosynthetically active radiation (GPP/PAR) was $26 \%$ stronger for offshore regimes than for onshore, while the ratio of ecosystem respiration to PAR (ER/PAR) was $71 \%$ stronger for offshore regimes. It was concluded that GPP maintains the same strength for both wind regimes, while ER is significantly stronger for offshore regimes, resulting in reduced NEE capacity during periods when winds originate from inland.

Keywords: global warming, carbon dioxide, photosynthesis, respiration, Hudson Bay Lowlands, advection, eddy covariance, peatlands 


\section{Introduction}

The carbon (C) balance of northern ecosystems plays an important role in observed and projected climate warming. Although the photosynthetic rates for peatlands are relatively low, the total amount of $\mathrm{C}$ stored in them is approximately $450 \times 10^{3} \mathrm{TgC}$, or about $30 \%$ of the global terrestrial C pool (Gorham 1991; Smith et al. 2004), as they represent strong C sinks in rich and slowly decomposing soils (Corradi et al. 2005). The Hudson Bay Lowlands, off the west coast of Hudson Bay, are the second largest continuous peatlands in the world, spanning $250,000 \mathrm{~km}^{2}$ and comprising $25 \%$ of Canada's wetlands (Riley 2011). In the northern portion of the Hudson Bay Lowlands within the Province of Manitoba, peat thickness reaches $4 \mathrm{~m}$, with an overall average depth of about $0.5 \mathrm{~m}$ (Dredge and Mott 2003). Accumulations over the past ca.4500 years are generally greatest inland and diminish towards the coast which is still progressing seaward as new land emerges from Hudson Bay due to isostatic uplift. The strength of the $\mathrm{C}$ sink is a result of inhibited decomposition in anerobic and frozen soil conditions (Burton et al. 1996; Cai et al. 2010), and it has been accumulating at a long term average rate of $21 \mathrm{gC} / \mathrm{m}^{2} /$ year (Clymo et al. 1998). However, projected climate warming, causing longer growing season, will likely affect northern ecosystems more strongly than in any other parts of the globe, with measurable consequences on the hydrological and carbon cycles (Cess et al. 1991; Rizzo and Wiken 1992; Chapman and Walsh 1993; Myneni et al. 1997; Serreze et al. 2000).

The amplification of the warming in the circumpolar north is primarily a result of positive feedback processes, most notably the surface-albedo/surface-temperature feedback, whereby increased air temperatures will result in the melting of snow and ice, which will further decrease the albedo, and enhance warming through greater absorption of solar radiation at the surface 
(Cess et al. 1991; Chapin et al. 2005; Hinzman et al. 2005). Another important positive feedback effect is from a prolonged thawing of carbon-rich permafrost soils, which could release stored organic $\mathrm{C}$ through microbial respiration in the form of carbon dioxide $\left(\mathrm{CO}_{2}\right)$ and methane $\left(\mathrm{CH}_{4}\right)$, depending on the water table depth. The carbon released under increasing temperatures further increases the greenhouse effect by contributing to the atmospheric $\mathrm{CO}_{2}$ concentration (Armentano and Menges 1986; Oechel et al. 1993; Zimov et al. 2006).

Although allowances are made within climate projection models for the interplay of feedback mechanisms, there still remain large uncertainties as to how some ecosystems will respond to a warming climate (Callaghan et al. 2004; Luo 2007; Heimann and Reichstein 2008), particularly in the north. Thus, it is important to quantify with field experiments the exchange of $\mathrm{CO}_{2}$ between northern ecosystems and the atmosphere that will increase our understanding of their functioning under future warming scenarios. Characterizing the drivers of $\mathrm{CO}_{2}$ exchange in Subarctic peatlands will establish the sensitivity of these active carbon sinks. In addition, warming temperatures have the potential to increase evaporation rates (Chapin et al. 2005) and dry out substantial areas of wetlands (Chivers et al. 2009). Peatlands are exceptionally vulnerable to drying out, as they have extremely large water contents when wet, and an equal amount of air content when dry (Rouse 2000), which suggests that a sink-source threshold of Net Ecosystem Exchange (NEE) is easy to cross. The sensitivity of these ecosystems is still uncertain, as some studies report that they are net sources of atmospheric $\mathrm{CO}_{2}$ (Griffis et al. 2000; Rouse et al. 2002), while others report them as sinks (Tans et al. 1990; Griffis et al. 2000; Aurela et al. 2002; Roulet et al. 2007; Cai et al. 2010). What is likely is that productive, peataccumulating wetlands have the potential to become large carbon sources under increasing air 
temperatures, which will induce greater respiration (Armentano and Menges 1986; Oeochel and Billings 1992; Zimov et al. 1999; Aurela et al. 2002; Dutta et al. 2006; Cai et al. 2010).

There have been a number of studies that have measured carbon fluxes in northern wetlands (Hamilton et al. 1994; Burton et al. 1996; Waddington and Roulet 1996; Griffis et al. 2000; Roulet et al. 2007), but the influence of Hudson Bay (via temperature and moisture) on these fluxes has not been investigated. Hudson Bay is a massive inland sea $\left(3.9 \times 10^{9} \mathrm{~km}^{2}\right)$ which historically was completely free of ice only in September (Danielson 1971) but more recently has attained ice-free status in August (Gagnon and Gough 2005). It is responsible for extending southward the range of Arctic flora and fauna, the continental treeline and permafrost into central Canada. The current rate of disappearance of sea-ice is $11 \%$ per decade since 1968 (Henry 2011), resulting in an extension of the ice-free season that will impact significantly on the surrounding terrestrial environment. An energy balance study by Rouse and Bello (1985) concluded that there is a strong dependence of the energy balance of three different sites $(1 \mathrm{~km}, 2$ $\mathrm{km}$ and $65 \mathrm{~km}$ inland) within the Hudson Bay Lowlands on the advective wind direction around Hudson Bay. This has been confirmed by others (Lafleur and Rouse 1988; Rouse et al. 1997). The current study serves as an extension to these findings to fill an important gap in our understanding of the advective influence of Hudson Bay on terrestrial carbon dynamics. It is expected that Ecosystem Respiration (ER) will increase with warmer soil temperatures, associated with offshore wind regimes, but the response of Gross Primary Productivity (GPP) to the same influences requires further investigation. Offshore wind regimes during the growing season are associated with warmer and drier air masses of continental origin, while onshore wind regimes are associated with cooler and moister air masses originating off the Bay. 
This study addresses the advective influence of Hudson Bay on the carbon dynamics of the Hudson Bay Lowlands at an elevated peat plateau near Churchill, Manitoba, Canada. The primary objectives are to (1) understand the environmental variables that influence the variability in NEE, GPP and ER of a Subarctic peat plateau during the growing season; (2) quantify the advective influence of Hudson Bay on the $\mathrm{CO}_{2}$ dynamics of the coastal peatlands through onshore and offshore wind analysis; (3) and ensure that measurement bias due to vegetation heterogeneity is addressed in flux computations. 


\section{Methods}

Study site description

Measurements for this study were collected between May 31, 2007 and September 18, 2007 as part of the ArcticNet Theme 3.2 campaign (ArcticNet 2015). The study was conducted at an elevated peat plateau, $20 \mathrm{~km}$ east of Churchill, Manitoba (58 43' 46"N, $\left.093^{\circ} 49^{\prime} 57^{\prime \prime} \mathrm{W}\right)$ and approximately $5 \mathrm{~km}$ south of the Hudson Bay coastline (Fig. 1) that runs east-west locally. The length of the day on the summer solstice is approximately 18.5 hours. The measurement site was located $17.5 \mathrm{~m}$ above sea level, with the ground gently sloping down towards the shore (3.5 $\mathrm{m} / \mathrm{km}$ ). Based on the elevation, the mineral soils at the site emerged from Hudson Bay approximately 1600 years ago, based on a $0.01 \mathrm{~m} /$ year isostatic rebound rate (Stella et al. 2007). The climate is classified as Low Arctic (Rouse 1993) with cold winters and large summer-winter temperature contrasts. Mean annual temperature is $-6.5^{\circ} \mathrm{C}$, and mean total precipitation is 452 $\mathrm{mm}$ with about $40 \%$ arriving as snow. The lowest daily average temperatures occur in January ($26.0^{\circ} \mathrm{C}$ ), and the highest daily average is in July $\left(12.7^{\circ} \mathrm{C}\right)$ (Environment Canada, 1981-2010 climate normal). The peat layer is $1.5 \mathrm{~m}$ thick, while maximum active layer depths are $45 \mathrm{~cm}$. The site is located approximately $80 \mathrm{~km}$ north of the continental treeline, with scattered trees such as Larix laricina (larch or tamarack) and Picea glauca (white spruce) present in low numbers locally with shrubs such as Salix spp. (willow) and Betula glandulosa (birch) common at greater distances from the tower. The peat plateau comprises high center ice-wedge polygons dominated by mosses (Dicranium elongatum, Tomenthypnum nitens, Aulocomnium spp.) and lichens (Cladina spp.) as well as Ericacae notably Rhododendron decumbens (dwarf labrador tea), Empetrum nigrum (crowberry), Vacinium vitis-ideae (low ground cranberry) and the herb 
Rubus chamaemorus (cloudberry). High center polygon peatlands dominate the inaccesible interior portion of the Hudson Bay Lowlands, comprising approximately $12,000 \mathrm{~km}^{2}$ in Northern Manitoba (Dredge and Nixon 1983; Bello and Smith1990) but are highly underrepresented in the coastal zone. The peat plateau under study is approximately 6 ha in areal extent and within $2 \mathrm{~km}$ of the Churchill Northern Studies Centre on the Twin Lakes Rd., providing a unique opportunity to examine net ecosystem exchange from habitats of this nature.

Throughout the growing season, the coastal zone of Hudson Bay is subjected to abrupt changes in weather owing to passages of frontal systems, as well as the effect of sea-breeze which can lower temperatures by as much as $25^{\circ} \mathrm{C}$ in a half-hour, especially when the Bay is still ice covered. In attributing a certain portion of the measured ecosystem response to changes in the accompanying air mass characteristics alone, throughout the various phenological stages of plant growth, it was important to first assess the extent to which differences in plant cover between the onshore and offshore directions might contribute to the observed differences in NEE. A detailed plant survey was conducted radially along 16 compass directions from the measurement tower in 22.5-degree increments, by measuring plant cover using $50 \mathrm{~cm}$ x $50 \mathrm{~cm}$ quadrats at $2 \mathrm{~m}$ intervals along each $100 \mathrm{~m}$ long transect. Understory cover comprised the vascular species, lichen, moss, water, rock while the overstory groups comprised the shrubs coniferous trees and cloudberry (Table 1). Cloudberry was classified as overstory due to its late leafout and large and variable proportionate cover compared to other vascular species. The influence of plant cover groups on measured $\mathrm{CO}_{2}$ fluxes for onshore and offshore regimes was assesssed using a weighted footprint analysis after Schuepp et al. (1990). The results were statistically tested (Table 2) to ensure that the site asymmetry did not influence the differences in measured fluxes. Plant cover proportions to the north and south were statistically different, but by less than $4.5 \%$ in all cases, well within 
the closure accuracy of the flux system, suggesting that the tower was optimally located for the purposes of this study.

\section{Instrumentation}

The micrometeorological method of eddy covariance (EC) was applied to measure the turbulent fluxes of $\mathrm{CO}_{2}$, latent and sensible heat in the surface layer. It directly measures the scalar constituents and correlates those measurements to vertical wind velocity to give vertical fluxes. The system consisted of two fast-response instruments; three-dimensional wind components were measured by a sonic anemometer, model ATI-V style, (Applied Technologies, Inc.) logging the $20 \mathrm{~Hz}$ median of $\mathrm{u}, \mathrm{v}, \mathrm{w}$ wind components sampled at $200 \mathrm{~Hz}$; the mean concentrations of $\mathrm{CO}_{2}$ and $\mathrm{H}_{2} \mathrm{O}$ were logged at $20 \mathrm{~Hz}$ using an non-dispersive open-path infrared gas analyzer (NDIR), model LI7500, (LI-COR Inc., Lincoln, NE, USA). Both instruments were mounted adjacent to each other separated by $12 \mathrm{~cm}$, at a height of $1.49 \mathrm{~m}$ above the peat surface, while the LI7500 was mounted with a slight tilt. Data were logged to a datalogger (Campbell Scientific Inc., CR3000) using serial and SDM communications.

Slow-response ancillary data were collected to describe the meteorological conditions of the site every 30 minutes. A net radiometer (Middleton CN1) was placed on an adjacent tower at the same height as the fast-response instruments, which measured the net radiation surrounding the tower as $\mathrm{Q}^{*}\left(\mathrm{~W} / \mathrm{m}^{2}\right)$. A pyranometer (Eppley PSP) measured incoming solar radiation as $\mathrm{R}_{\mathrm{g}}$ $\left(\mathrm{W} / \mathrm{m}^{2}\right)$; three soil heat flux plates (Middleton $\mathrm{CN} 3$ ) were placed at $2 \mathrm{~cm}$ below the surface as $\mathrm{Q}_{\mathrm{G}}$ $\left(\mathrm{W} / \mathrm{m}^{2}\right)$. The slow-response instruments were connected to a Campbell Scientific CR23x data logger. PPFD (photosynthetic photon flux density) was acquired by applying a linear model to 
the $\mathrm{R}_{\mathrm{g}}$ data. The linear model was developed from the data collected at an EC station approximately $1 \mathrm{~km}$ away.

\section{Data Processing}

The high frequency flux data were processed with an open-source EC software, EddyPro 4.1.0 (LI-COR Biogeosciences, Lincoln, NE, USA). The eddy fluxes were calculated as the covariance between turbulent fluctuations in the vertical wind component and the scalar densities of $\mathrm{CO}_{2}$ and $\mathrm{H}_{2} \mathrm{O}$ using covariance optimization for time lag compensation. The data were averaged over 30 minutes, derived from Reynolds block averaging for trend removal. The sonic anemometer was adjusted for tilt using the planar fit method (Wilczak et al. 2001) by taking into account wind fields observed throughout the data collection period. High-pass filtering for low frequency data loss was performed using a block average detrend method after Moncrieff et al. (2004). A low-pass high frequency filter for data loss in the high frequency range was performed after Moncrieff et al. (1997), which accounts for the lateral and longitudinal sensor separation, sensor time response, scalar and vector path averaging (Foken et al. 2008). An off-season uptake correction has been performed to account for additional instrument-related sensible heat flux generation during temperatures below $-10{ }^{\circ} \mathrm{C}$, following a method proposed by Burba et al. (2008). The fluxes were corrected for the effect of temperature and humidity fluctuations in trace gas concentrations that were not part of the investigated flux, using the WPL correction (Webb et al. 1980). Periods when less than $90 \%$ of the high frequency flux was available were marked as missing values and addressed during the post-processing. The resultant 30 -minute $\mathrm{CO}_{2}$ fluxes represent NEE, or the balance between the total flux that entered the ecosystem and the total flux that left the ecosystem. 


\section{Post Processing}

The flux data were flagged using the 1-9 system after Foken (2004), which incorporates a steady-state, integral turbulence test, and horizontal advection tests. As advised, classes 7-9 have been removed from the dataset and marked as missing data, accounting for $6.9 \%$ of the total data. Data loss due to adverse weather and instrument malfunctioning accounted for $16 \%$ of the total data. Data loss due to data failing statistical analysis tests, performed after Vickers and Mahrt (1997), and after manual screening accounted for $7.3 \%$. Of the remaining data, approximately $4.9 \%$ of the nighttime fluxes were removed using a $u$. filter. For the removal of periods under non-turbulent conditions, the $u$ • filter was applied after Reichstein et al. (2005). The method involves the binning of temperature values to produce 6 temperature classes, which are further subdivided into $20 u$. classes. The $u$. threshold value was determined to be 0.082 $\mathrm{m} / \mathrm{s}$. The total data loss added up to $35.1 \%$, which was gap-filled. A random error of \pm 0.12 $\mu \mathrm{mol} / \mathrm{m}^{2} / \mathrm{s}$ was estimated following Moncrieff et al. (1996).

Since the EC method is only able to measure NEE, it is necessary to partition it into the two component fluxes that make up the total exchange - ER and GPP. In order to obtain ER, we used one of the most common methods which employs nighttime respiration data as a function of air temperature and apply the same relationship to daytime values. Respiration has been modeled using an Arrhenius equation modified by Lloyd and Taylor (1994) as an exponential regression model derived from all available, non-gap-filled 30-min fluxes: 
$E R=E R_{r e f} e^{\left[E_{0}\left(\frac{1}{T_{r e f}-T_{0}}\right)-\left(\frac{1}{T-T_{0}}\right)\right]}$

where $E R_{r e f}$ is the respiration rate at the reference temperature, $T_{r e f}$, set to $10^{\circ} \mathrm{C}$ and $T_{0}$ is the regression parameter kept constant at $-46.02^{\circ} \mathrm{C}$ as in the original model. The activation energy parameter , $E_{o}$, was adjusted to achieve the most optimal model fit.

The gap-filling was done after Falge et al. (2001) and modified by Reichstein et al. (2005). Single 30-minute gaps were filled by linear interpolation (Falge et al. 2001); larger gaps were filled using mean diurnal variation with a 14-day window that looks for the flux under similar atmospheric conditions (global radiation $\left(\mathrm{R}_{\mathrm{g}}, \mathrm{W} / \mathrm{m}^{2}\right)$ air temperature $\left({ }^{\circ} \mathrm{C}, \mathrm{T}\right)$, vapour pressure deficit (kPa, VPD)) (Reichstein et al. 2005), which was the most consistent method based on 15 different methods analyzed by Moffat et al. (2007). The gaps in the energy fluxes were filled in the same manner.

\section{Data Treatment}

In order to better understand and quantify the effects of Hudson Bay on the Hudson Bay Lowlands, the flux data were differentiated between onshore and offshore wind regimes. The study site was situated on a nearly perpendicular tangent with respect to the Hudson Bay shoreline, which runs due east to west. For this reason, winds originating from north of the eastwest tangent were considered to be onshore winds; winds originating from south of the east-west tangent were considered to be offshore winds. Due to the smaller frequency of onshore wind regimes taking place at night, the analysis concentrates on monthly averages using daytime 
values, which are representative of both wind regimes. The monthly average is considered a long enough time period to gather data that are representative of both wind regimes.

In order to assess how well the EC system performed, the energy balance closure was considered, calculated as the ratio of $\frac{Q_{H}+Q_{E}}{Q^{*}-Q_{G}}$, where $Q^{*}$ is net radiation, $Q_{H}$ is the sensible heat flux, $Q_{E}$ is the latent heat flux and $Q_{G}$ is the ground heat flux, all in units of $\mathrm{W} / \mathrm{m}^{2}$. On average, the system underestimated the turbulent fluxes, but there was a difference between onshore and offshore regimes. During onshore regimes, the closure was $87 \%$, while under offshore regimes it was $64 \%$. The difference may be due to larger amount of offshore regimes occurring during nighttime hours which commonly results in more stable atmospheric conditions. Other northern peatland studies have reported energy balance closure between $70 \%$ and $91 \%$ (Lafleur et al. 2001; Lafleur et al. 2003; Sottocornola and Kiely 2010; Runkle et al. 2014). The fluxes presented have been compensated to achieve energy balance closure.

Given that the datatset was post-processed to produce just two test groups - onshore and offshore - the statistical tests performed for this study were student's two-tailed t-tests assuming equal variances. 


\section{Results}

\section{Environmental Conditions}

During the calendar year of 2007 , the mean daily air temperature was $-9.9^{\circ} \mathrm{C}$, slightly cooler than the climate normal of $-6.5^{\circ} \mathrm{C}$ (Table 3 ). During the study period, July experienced the highest mean temperature of $15.4^{\circ} \mathrm{C}$, while September had the lowest mean temperature of $5.4^{\circ} \mathrm{C}$. All normal monthly temperatures were within \pm 1 standard deviation of the observed mean monthly temperatures, except for July, which was 2 standard deviations higher than the climate normal. The 2007 calendar year was drier than normal, with $338 \mathrm{~mm}$ of precipitation, compared to a 30 -year average of $432 \mathrm{~mm}$. The observed precipitation values were 48.2 (44.2), 30.2 (59.8), 44.4 (69.4) and 87.5 (69.9) mm for June, July August and September, respectively; bracketed numbers are climatological values. Thus, July and August were slightly drier and warmer than average.

The precipitation (P) and evaporation (E) patterns over the study period are shown in Fig. 2, during which evaporation exceeded precipitation for most of the season. For a nearly twoweek period from DOY 160 to DOY 170, precipitation exceeded evaporation, associated with spring showers, but lower temperatures suppressed a strong evaporation response. The daily evaporation rates decreased over the season and were especially low into September when the evaporation rate decreases and the energy receipt was low. The total evaporation during the measurement period was $218 \mathrm{~mm}$, while the total rainfall amounted to $193 \mathrm{~mm}$, resulting in an 
evaporative efficiency (E/P) of 1.12, indicating a net decline of ecosystem water storage and a receding water table.

Temperature Regimes

The differences in meteorological conditions between the two wind regimes were most pronounced for temperature (Fig. 3). The distinctive differences in diurnal behavior between onand offshore regimes are noteworthy, as offshore air temperatures rose significantly during the daytime, while onshore temperatures exhibited much smaller maxima, owing to the large differences in surface sensible heat exchange between the tundra and Hudson Bay. In June, the onshore diurnal temperatures did not rise beyond $6^{\circ} \mathrm{C}$, while the offshore temperatures hovered around $10^{\circ} \mathrm{C}$ during the daytime hours. Both regimes experienced a pronounced warming into July, where the daytime highs averaged $16^{\circ} \mathrm{C}$ for onshore and $23^{\circ} \mathrm{C}$ for offshore. Into August, both regimes cooled, with the offshore temperatures continuing to be warmer, while September temperatures showed patterns similar to June. Thus, the study was able to capture the diurnal temperature variation during the growing season that contributed to the significant plant activities of photosynthesis and respiration. On average for the season, offshore $\mathrm{T}$ was $4.15^{\circ} \mathrm{C}$ higher than onshore, highlighting the importance of the thermal depression created by Hudson Bay.

\section{Energy Balance}


Q* appeared to be larger when winds were blowing offshore during the two coldest months, June and September, associated with the greatest onshore-offshore temperature contrast (Fig. 4). A reversed pattern is observed for July and August, where onshore regimes were associated with greater $\mathrm{Q}^{*}$. $\mathrm{Q}_{\mathrm{G}}$ showed stronger soil warming during offshore regimes in June and September, but a reversed role during July and August. Over the entire growing season, the ground experienced a net gain of $60 \mathrm{MJ} / \mathrm{m}^{2}$ through surface exchange during onshore regimes, while $28 \mathrm{MJ} / \mathrm{m}^{2}$ entered the ground during offshore regimes. $\mathrm{Q}_{\mathrm{H}}$ was higher for onshore than offshore wind regimes, with a progressive decrease over the measurement period, rather than peaking during July when $\mathrm{Q}^{*}$ and $\mathrm{T}$ experienced their highest values. By the end of the season, onshore and offshore sensible heating amounted to $377 \mathrm{MJ} / \mathrm{m}^{2}$ and $79 \mathrm{MJ} / \mathrm{m}^{2}$, respectively. $\mathrm{Q}_{\mathrm{E}}$ was smaller during onshore regime for June and September. At the end of the measurement period, onshore and offshore $\mathrm{Q}_{\mathrm{E}}$ amounted to $365 \mathrm{MJ} / \mathrm{m}^{2}$ and $173 \mathrm{MJ} / \mathrm{m}^{2}$, respectively. The seasonal flux totals were strongly influenced by the higher frequency ( $56 \%$ larger) of onshore wind.

Table 4 shows normalized values of $\mathrm{Q}_{\mathrm{H}}, \mathrm{Q}_{\mathrm{E}}$, and $\mathrm{Q}_{\mathrm{G}}$ with respect to $\mathrm{Q}^{*}$ by dividing each of them by $\mathrm{Q}^{*}$. The ratios were derived from an average of all 30-minute daytime measurement periods occurring in the onshore or the offshore directions for a given month, from June through September. The partitioning of net radiation into evaporation does not show statistically significant onshore-offshore differences for any month although there was an apparent increase of $15 \%$ over the entire season existed while winds were blowing offshore. The proportion of net radiation used in warming the atmosphere, $\mathrm{Q}_{\mathrm{H}} / \mathrm{Q}^{*}$, was consistently larger during onshore regimes. Lastly, the proportion of net radiation used in ground heating, $\mathrm{Q}_{\mathrm{G}} / \mathrm{Q}^{*}$ tended to be 
stronger during offshore wind regimes on average for all months, particularly in July and August and $64 \%$ larger on average over the entire season.

Response of GPP, ER and NEE to Microclimate Variables

Daily average NEE during the four month period ranged from $-0.2 \mu \mathrm{mol} / \mathrm{m}^{2} / \mathrm{s}$ in the middle of September (JD 261), to $-5.6 \mu \mathrm{mol} / \mathrm{m}^{2} / \mathrm{s}$ towards the end of July (JD 207) (Fig. 5). The month of June experienced a relatively consistent net uptake of $\mathrm{CO}_{2}$ of about $-1.5 \mu \mathrm{mol} / \mathrm{m}^{2} / \mathrm{s}$, but started to increase (higher negative values) in early July (around DOY 170). However, the net uptake started to decrease in August and by the end of September, the NEE values started to approach zero. The ecosystem was a consistent net sink for $\mathrm{CO}_{2}$ throughout the measurement period. On a monthly basis, the largest uptake occurred in July $\left(53.0 \mathrm{gC} / \mathrm{m}^{2}\right.$ or $\left.4.4 \mathrm{~mol} / \mathrm{m}^{2}\right)$, while the lowest uptake occurred in August $\left(25.5 \mathrm{gC} / \mathrm{m}^{2}\right.$ or $\left.2.13 \mathrm{~mol} / \mathrm{m}^{2}\right)$. Although GPP was larger in August $\left(113.9 \mathrm{gC} / \mathrm{m}^{2}\right.$ or $\left.9.49 \mathrm{~mol} / \mathrm{m}^{2}\right)$ than in June $\left(80.7 \mathrm{gC} / \mathrm{m}^{2}\right.$ or $\left.6.73 \mathrm{~mol} / \mathrm{m}^{2}\right)$, the ecosystem respiration was substantially higher in August $\left(88.4 \mathrm{gC} / \mathrm{m}^{2}\right.$ or $\left.7.37 \mu \mathrm{mol} / \mathrm{m}^{2}\right)$ than in June $\left(48.7 \mathrm{gC} / \mathrm{m}^{2}\right.$ or $\left.4.06 \mathrm{~mol} / \mathrm{m}^{2}\right)$.

The distinctiveness of ecosystem functioning under opposing wind regimes is shown in Table 5, as monthly means calculated from all 30-minute daytime measurements. Net ecosystem exchange was consistently larger under onshore regimes with statistically significant differences for all months except September, with the largest difference of $37 \%$ in July. Ecosystem respiration was always larger during offshore winds, ranging from $20 \%$ higher in August to $45 \%$ higher in June. 
Monthly average GPP differences are less apparent over the summer, as GPP was higher during offshore regimes in June and September only. Over the entire measurement period, there is no statistically significant difference in GPP between onshore and offshore regimes. ER, GPP and NEE monthly averages do not account for potential biases created by the diurnal timing of onshore and offshore winds, particularly those that may occur as a result of the sea breeze effect. Thus, carbon fluxes have been normalized to photosynthetically active radiation (PARx100), in Table 5, which reveals a stronger photosynthetic efficiency during offshore winds; up to $32 \%$ stronger in July.

Similarly, PAR-normalized ecosystem respiration was always stronger for offshore winds; up to $91 \%$ stronger in July. The interplay between GPP and ER, reflected in the ratio of the two, ER/GPP, describes how much of GPP is offset by ER. For all months and therefore the entire season, ER/GPP was always larger when winds were offshore, implying that a greater proportion of assimilation was returned to the atmosphere through respiration during offshore regimes. The ecosystem remained a net sink for $\mathrm{CO}_{2}$, except for September under offshore regimes, where ER was 28\% larger than GPP. As a seasonal average, offshore ER/GPP was 67\% higher than onshore ER/GPP.

The onshore/offshore light response curves (Fig. 6a) show little deviation from each other and are not significantly different $(\mathrm{p}>0.05)$, using the Student-t test mentioned in the Method section. It is apparent that the sensitivity of GPP to PAR is the same regardless of air mass origin. However, for the same light levels, onshore conditions are cooler (Fig. 6b). This suggests that despite cooler temperatures, they are able to keep up with offshore GPP rates owing to enhanced onshore light levels. This suggests that the rates of ER between onshore and offshore wind regimes are more influential in the determination of NEE than GPP is. 
The thermal response of the carbon flux is shown graphically for binned air temperatures for onshore and offshore wind regimes (Fig. 7a,b). Onshore GPP is consistently higher than offshore GPP at a given temperature, but the difference quickly diminishes after $20^{\circ} \mathrm{C}$ (Fig. $7 \mathrm{a}$ ). Beyond $20^{\circ} \mathrm{C}$ offshore GPP experiences a slower increase, although values should be interpreted with caution as less data points were available for the averaging calculation at such high temperatures. NEE, comprising both GPP and ER, (Fig. 7b) shows a large difference between the onshore and offshore winds at the same temperature, with intermediate temperatures (11$20^{\circ} \mathrm{C}$ ) demonstrating the largest difference in favour of onshore winds, which also coincides with the highest frequency of occurrence. Given that GPP values do not differ between onshore and offshore regimes at the same PAR (Fig. 6), other environmental factors that influence the carbon flux need to be considered. As Fig. 6b suggests, the origin of the air mass does not play a role in determining the strength of GPP, while it strongly influences the fate of ER through the apparent sensitivity of temperature through the covariance of PAR and temperature.

\section{Discussion}


Interplay Between Fluxes

The results of the interplay between GPP and ER under the influence of different environmental conditions reveals important aspects of the Hudson Bay Lowlands as a coastal environment where Hudson Bay's overall influence is intermittently imposed on the adjacent landscape, even up to $60 \mathrm{~km}$ inland as reported by Rouse and Bello (1985). The progression of daily average NEE over the growing season in 2007 was consistent with the pattern observed for other years at a nearby location (Lafleur et al. 2012). Although data presented here reflect ecosystem dynamics of a single year, the patterns are such that they are representative of the generic ecosystem function, although magnitudes may change inter-annually. At the beginning of the season, the flux was relatively strong $\left(-2 \mu \mathrm{mol} / \mathrm{m}^{2} / \mathrm{s}\right)$ even shortly after snowmelt, a process described by Aurela et al. (2002). Since a thin layer of snow can drastically alter the energy balance of an ecosystem, complete snowmelt allows for increased net radiation and the concurrent onset of photosynthesis, largely due to the presence of mosses and lichens (Oechel and Collins 1976). Bryophytes begin photosynthesizing immediately after snowmelt, making them important contributors earlier in the season before many vascular plants have leafed out. In September, the NEE abruptly dropped from its August levels, similar to Lafleur et al. (2012), indicating a quick senescence common to northern environments (Corradi et al. 2005; Lund et al. 2010). At this time of the year, daylength shortens, light levels decrease and temperatures are much cooler, unable to sustain strong photosynthesis.

Total GPP during the measurement period was $391 \mathrm{gC} \mathrm{m}^{-2}$ of which $66 \%$ occurred during onshore wind regimes, while responding to a number of environmental controls that mutually 
contribute to stronger onshore $\mathrm{CO}_{2}$ uptake. For the same temperature, onshore light levels consistently exceeded offshore levels, which was reflected in higher onshore GPP for any given temperature. The strong association between light levels and GPP with respect to marine origin air masses has also been documented by Lafleur and Rouse (1988). The onshore GPP strength for a given temperature, as shown in Fig. 7a, is directly translated into enhanced onshore NEE (Fig. 7b), as a direct consequence of the slope difference between onshore and offshore GPP rise with increasing temperatures.

The analysis reveals that GPP is less sensitive to temperature than ER, a result consistent with the findings of others (Billings et al. 1982; Silvola et al. 1996; and McGuire et al. 2000), regardless of air mass origin. Others report the opposite (McKane et al. 1997) or similar temperature sensitivities (Chivers et al. 2009), who attribute enhanced GPP in warmer soils to an increase in nutrient availability at Arctic tundra sites. In the current study, it is unlikely that changes in nutrient availability would accompany abrupt changes in air mass origin on a time scale of several hours. The results suggest that with increasing temperatures in the Arctic, the plant community will assimilate more $\mathrm{CO}_{2}$ under onshore regimes compared to offshore regimes, if light level differences remain the same between the two regimes. Considering the small dataset representing temperatures beyond $20^{\circ} \mathrm{C}$, it would be difficult to predict how light levels will change under a warming climate, requiring further research. Nevertheless, the Bay is associated with high pressure systems due to cooler temperatures and restricted moisture availability as a result of ice cover, contributing to clear skies under onshore regimes. This illustrates its strong influence on the surrounding coastal ecosystems, brought on by its current ice cover conditions. 


\section{Energy Balance and Permafrost}

The partitioning of the coastal energy balance is expected to have a significant effect on the heat flow within the soil columns and within the boundary layer. The way energy is partitioned at the land surface directly influences the micrometeorological conditions of the ecosystem through the interaction between heat and moisture and potentially temperature and precipitation. Average net radiation does not show a difference between onshore and offshore regimes, but its partitioning into $\mathrm{Q}_{\mathrm{E}}, \mathrm{Q}_{\mathrm{H}}$ and $\mathrm{Q}_{\mathrm{G}}$ does. Although the mean onshore/offshore $\mathrm{Q}_{\mathrm{E}} / \mathrm{Q}^{*}$ is not statistically different, $46 \%$ of the growing season evaporation occurred when air masses were of marine origin. Rouse and Bello (1985) showed a similar pattern for their sea, near-coast and inland sites, illustrating the suppression of evaporation due to reduced vapor pressure gradients caused by the advective influence of moist cool air off Hudson Bay. The sensible heat flux increases strongly in response to cool air masses originating from the Bay, thereby lowering surface temperatures and removing energy that would have otherwise been utilized by $\mathrm{Q}_{\mathrm{G}}$ for permafrost degradation. This, in turn, reduces the vertical temperature gradient into the soil suppressing the ground heat flux as a result of the Bay's presence (Rouse 2000). For tundra sites, a large proportion of summertime net radiation $(\sim 10-20 \%)$ is normally consumed in ground heating as a consequence of a sparse canopy and proximity of the frost table. (Lafleur et al.1997; Eugster et al. 2000; Kellner 2001). The enhanced ground heating observed during offshore regimes increases soil temperatures and active layer growth, both contributing to heterotrophic decomposition, especially in soils comprised entirely of peat that house nonvascular plants (Callaghan et al. 2004). This is represented in the measured ecosystem respiration being especially sensitive to the changing wind direction and the air temperatures associated with those winds. 
Expectations under a Warming Climate

In the mid 80's and 90's, northern latitudes were generally considered to be sinks for atmospheric $\mathrm{CO}_{2}$ (Tans et al. 1990; Ciais et al. 2000) but with increasing global temperatures this may change. Extensive studies on carbon dynamics have demonstrated that temperature has an observed influence on NEE (Callaghan et al. 2004; Groendahl et al. 2007; Parmentier et al. 2011), although others have not found a strong link (Griffis et al. 2000; Aurela et al. 2004). As part of a dynamic system, there exist many nonlinear interacting processes within the carbon dynamical processes that would influence the net flux of carbon at the surface. But based on our field observations, we think there are two potential outcomes under a warming climate, where carbon sinks strengthen due to altered biogeochemical processes or where carbon stocks become sources due to increased respiration. Based on shown results, we expect the ecosystem to begin to undergo conditions typical of offshore wind regimes in a more pronounced fashion, characterized by higher temperatures, enhanced ground warming and active layer deepening, greater evaporation, and reduced light levels. The results presented here show that although offshore wind regimes produce GPP rates comparable to onshore, they are associated with a stronger increase in ER, making such regimes weaker sinks and supporting the second scenario.

Since higher temperatures are expected to prolong the growing season (Myneni et al. 1997) a shift in vegetation dynamics is to be expected alongside. This is anticipated to increase carbon stocks by accumulating newer and larger quantities of organic matter into the peat (Aurela et al. 2004; Euskirchen et al. 2006; Schuuer et al. 2008). In accord with results presented in this study, Parmentier et al. (2011) conducted a multi-year analysis of NEE, GPP and ER, and concluded that longer growing season and warmer temperatures do not increase the NEE uptake 
in their Siberian location, mainly a result of increased ER sensitivity to increased air temperatures in comparison to GPP; similar results were found by others (Dorrepaal et al. 2009; Cai et al. 2010). Consequently, northern ecosystems adapted to cold climate will not benefit by increased air temperatures with respect to carbon sequestration, as reinforced by our results and those of others (Fan et al. 2013). Instead, warmer air masses due to large-scale circumpolar warming are likely to skew the carbon flux towards increased respiration and decreased total carbon uptake during both onshore and offshore regimes. In addition to this global trend, the gradual disappearance of sea ice is expected to drive local and regional warming by altering the composition of the onshore air mass.

At the present time, the geographical situation of Hudson Bay predisposes it to having nearly complete year-round ice cover, except for two months. In August and September, the Bay is completely ice-free and summer and fall are characterized by 30 -year negative sea-ice cover trends (Barber et al. 2012; Cavalieri and Parkinson 2012). This will have a significant influence on the atmospheric circulation regime over the Hudson Bay region. In addition to the influence of increasing global and regional temperatures on the make-up of onshore and offshore air masses, temperature is likely a driver for shifting winds. Positive temperature anomalies are correlated with negative sea-ice trends, most pronounced on the western and south-western part of the Bay, showing a decrease of $23.3 \%$ to $26.9 \%$ per decade since 1980 (Hochheim and Barber 2010). Evidence of changing wind regimes is presented by Hochheim et al. (2011), who found that anti-cyclonic atmospheric rotation occurs under high sea level pressure and low land surface pressure, resulting in onshore regimes. This pattern has been observed prior to 1989 , whereas the post 1989 period is characterized by cyclonic atmospheric circulation which results from low sea level pressure and high land surface pressure, resulting in offshore winds. These results are 
consistent with the qualitative indication of the decreasing frequency of onshore winds, compared to offshore winds (Fig. 8) during the month of June. The month of June behaves as a transitional month between ice-covered and ice-free water in Hudson Bay, and therefore is an indication of the encroaching offshore winds in the past, present and in the future. The decrease in onshore wind frequency will result in a weakened advective influence of Hudson Bay on the coastal Hudson Bay Lowlands, thereby increasing air and soil temperatures and decreasing the strength of the carbon sink. The conclusions reached are reinforced by those found by Rouse and Bello (1985) who identified a modest shift from onshore to offshore wind regimes as a result of advanced melting in the early growing season. The observed shift from onshore to offshore regimes in conjunction with melting sea ice will weaken the carbon sink of the coastal Hudson Bay Lowlands, in consequence reducing its capacity to sequester the increasing concentration of $\mathrm{CO}_{2}$ in the atmosphere. A probable shift to more frequent offshore winds coupled with circumpolar scale air warming has significant implications for the degradation of permafrost through a deepening of the active layer, which has already been noted to occur (Payette et al. 2004).

During the 2007 growing season, the peat plateau experienced a substantial net gain of carbon, $116 \mathrm{gC} / \mathrm{m}^{2}$. If the respiration before and after the growing season is accounted for by using the measured air temperatures from the Churchill airport (Environment Canada 2013) and using the respiration model described by Lloyd and Taylor (1994), the sequestered amount reduces to $27 \mathrm{gC} / \mathrm{m}^{2} /$ year, which is relatively close to the long term value of $23 \mathrm{gC} / \mathrm{m}^{2} /$ year estimated by Gorham (1991) for northern peatlands. Yet, this represents only $9.8 \%$ and $6.9 \%$ of annual GPP and ER, respectively, which is comparable to potential measurement errors. It is noteworthy that this coastal peat plateau comprises close to $50 \%$ vascular plant cover which is 
not necessarily representative of ice-wedge polygon systems in general. Nevertheless, if this value is extrapolated to the entire area of the Hudson Bay Lowlands of $250,000 \mathrm{~km}^{2}$, the uptake corresponds to $6.7 \mathrm{MtC} /$ year. It is important to note the large uncertainty in extrapolating the carbon flux of a small area over the vast and heterogeneous ecosystems of the Hudson Bay Lowlands, however it does highlight the role tundra ecosystems in cold environments can play in mitigating anthropogenic emissions.

\section{Conclusion}

The difference in the $\mathrm{CO}_{2}$ flux from upland tundra during onshore and offshore wind regimes was measured using the EC method in the Hudson Bay Lowlands near Churchill, MB. During the 2007 growing season, the peat plateau experienced a substantial net gain of carbon, $116 \mathrm{gC} / \mathrm{m}^{2}$

It was confirmed that the Hudson Bay has an advective influence on the carbon dynamics and energy balance of the coastal Hudson Bay Lowlands as others have concluded (Rouse and Bello 1985; Lafleur and Rouse 1988; Rouse et al. 1997). The $\mathrm{CO}_{2}$ flux between the two wind regimes differed significantly, reinforcing the importance of Hudson Bay as mostly frozen water body dominated by onshore wind regimes. When normalized to PAR, there was no statistical difference between the GPP of onshore and offshore regimes, yet the offshore air temperature was significantly higher than the onshore air temperature. This suggests that although air temperatures have no effect on the difference of onshore and offshore GPP, ER is responsive to air mass origin. The strong response of ER is associated with different $\mathrm{Q}_{\mathrm{H}}$ energy portioning, whereby onshore regimes remove energy that would otherwise warm the permafrost, while 
offshore regimes add energy that contributes to permafrost degradation. This indicates a potential deterioration of the $\mathrm{CO}_{2}$ budget of the Hudson Bay Lowlands under projected climate warming and sea ice reduction. As such, a better understanding of meso-scale wind regimes and sea ice dynamics under a warming climate is needed to have the ability to accurately project the future response of the coastal Hudson Bay Lowlands. Nevertheless, the observed shift from onshore to offshore regimes in conjunction with melting sea ice will weaken the carbon sink of the Hudson Bay Lowlands, in consequence reducing its capacity to sequester the increasing global emissions.

\section{Acknowledgements}

The authors would like to acknowledge the funding support of ArcticNet, the Department of Aboriginal Affairs and Northern Development Canada through the Northern Scientific Training Program, The Faculty of Liberal Arts and Professional Studies, York University, and the Churchill Northern Studies Centre through the Northern Research Fund. The logistical support of Clifford Paddock and staff of the Churchill Northern Studies Centre, Dr. Mario Tenuta and Dr. Tim Papakyriakou of the University of Manitoba is gratefully acknowledged. Field assistance was provided by Robert Whitten, Patrick Mojdehi, Kyle Switsyn, Ryan Rimas and Patrick Shuman and was instrumental to the success of this project. The authors would also like to thank the two anonymous reviewers who provided valuable criticism to this paper. 


\section{References}

ArcticNet. 2015. Theme 3 - Managing the Largest Canadian Watershed in a New Climate: LandOcean Interactions in Sub-Artic Hudson Bay. Research. Data Accessed: December 21, 2015. < http://www.arcticnet.ulaval.ca/research/theme3.php $>$

Armentano, T.V., and Menges, E.S. 1986. Patterns of change in the carbon balance of organic soil-wetlands of the temperate zone. Journal of Ecology, 74,755-774.

Aurela, M., Laurila, T., and Tuovinen, J.P. 2002. Annual $\mathrm{CO}_{2}$ balance of a subarctic fen in northern Europe: Importance of the wintertime efflux. Journal of Geophysical Research, 107, $17-1-17-12$.

Aurela, M., Laurila, T., and Tuovinen, J.P. 2004. The timing of snow melt controls the annual $\mathrm{CO}_{2}$ balance in a subarctic fen. Geophysical Research Letters, 31, GL20315.

Aurela, M., Riutta, T., Laurila, T., Tuovinen, J.P., Vesala, T., Tuittila, E.S., Rinne, J., Haapanala, S., and Laine, J. 2007. $\mathrm{CO}_{2}$ exchange of a sedge fen in southern Finland - the impact of a drought period. Tellus, 59B, 826-837.

Barber, D.G., Asplin, M.G., Raddatz, R.L., Candlish, L.M., Nickels, S., Meakin, S., Hochheim, K.P., Lukovich, J.V., Galley, R.J. and Prinseberg, S.J. 2012. Change and variability in sea ice during the 2007-2008 Canadian International Polar Year program. Climatic Change, 115, 115-133.

Bello, R.L., and Smith, J.D. 1990. The effects of weather variability on the energy balance of the lake in the Hudson Bay Lowlands, Canada. Arctic and Alpine Research, 22, 1, 98-107.

Billings, W.D., Luken, J.O., Mortensen, D.A., and Peterson, K.M. 1982. Arctic tundra: A source or a sink for atmospheric carbon dioxide in a changing environment? Oecologia, 53, 711. 
Burba, G.G., Mc Dermitt, D., Grelle, A., Anderson, D.J., and Xu, L. 2008. Addressing the influence of instrument surface heat exchange on the measurements of $\mathrm{CO}_{2}$ flux from open-path gas analyzers. Global Change Biology, 14:1854-1876.

Burton, K.L., Rouse, W.R., and Boudreau, L.D. 1996. Factors affecting the summer carbon dioxide budget of subarctic wetland tundra. Climate Research, 6, 203-213.

Cai, T., Flanagan, L.B., and Syed, K.H. 2010. Warmer and drier conditions stimulate respiration more than photosynthesis in a boreal peatland ecosystem: Analysis of automatic chambers and eddy covariance measurements. Plant, Cell and Environment, 33, 394-407.

Callaghan, T.V., Bjorn, L.O., Chernov, Y., Chapin, T., Christensen, T.R., Huntley, B., Ims, R.A., Johansson, M., Jolly, D., Jonasson, S., Matveyeva, N., Panikov, N., Shaver, G., Schaphoff, S., and Sitch, S. 2004. Effects of changes in climate on landscape and regional processes, and feedbacks to the climate system. Ambio, 33, 459-468.

Cavalieri, D.J., and Parkinson, C.L. 2012. Arctic sea ice variability and trends, 19679-2010. The Cryosphere, 6, 881-889.

Cess, R.D., Potter, G.L., Zhang, M.H., Blanchet, J.P., Chalita, S., Colman, R., Dazlich, D.A., Del Denio, A.D., Dymnikov, V., Galin, V., Jerrett, D., Keup, E., Lacis, A.A., Le Treut, H., Liang, X.Z., Mahfouf, J.F., McAvaney, B.J., Meleshko, V.P., Mitchell, J.F.B., Morcrette, J.J., Norris, P.M., Randall, D.A., Rikus, L., Roeckner, E., Royer, J.F., Schlese, U., Sheinin, D.A., Slingo, J.M., Sokolov, A.S., Taylor, K.E., Washington, W.M., Wetherald, R.T., and Yagai, I. 1991. Interpretation of snow-climate feedback as produced by 17 general circulation models. Science, 253, 888-892.

Chapin III, F.S., Strum, M., Serreze, M.C., McFadden, J.P., Key, J.R., Lloyd, A.H., McGuire, A.D., Rupp, T.S., Lynch, A.H., Schimel, J.P., Beringer, J., Chapman, W.L., Epstein, H.E., Euskirchen, E.S., Hinzman, L.D., Jia, G, Ping, C.L., Tape, K.D., Thompson, 
C.D.C., Walker, D.A., and Welker, J.M. 2005. Role of land-surface changes in Arctic summer warming. Science, 310, 657-660.

Chapman, W.L., and Walsh, J.E. 1993. Recent variations of sea ice and air temperature in high latitudes. Bulletin of the American Meteorological Society, 74, 33-47.

Chivers, M.R., Turetsky, M.R., Waddington, J.M., Harden, J.W., and McGuire, A.D. 2009. Effects of experimental water table and temperature manipulations on ecosystem $\mathrm{CO}_{2}$ fluxes in an Alaskan rich fen. Ecosystems, 12, 1329-1342.

Ciais, P., Peylin, P., and Bousquet, P. 2000. Regional biospheric carbon fluxes as inferred from atmospheric $\mathrm{CO}_{2}$ measurements. Ecological Applications, 10, 1574-1589.

Clymo, R.S., Turunen, J., and Tolonen, K. 1998. Carbon accumulation in peatland. OIKOS, 81, 368-388.

Corradi, C., Kolle, O., Walter, K., Zimov, S.A., and Schulze, E.D. 2005. Carbon dioxide and methane exchange of a north-yeast Siberian tussock tundra. Global Change Biology, 11, 1910-1925.

Danielson Jr., E.R. 1971. Hudson Bay ice conditions. Arctic, 24, 90-107.

Dorrepaal, E., Toet, S., van Logtestijn, R.S.P., Swart, E, van de Weg, M.J., Callaghan, T.V., and Aert, R. 2009. Carbon respiration from subsurface peat accelerated by climate warming in the subarctic. Nature, 460, 616-620.

Dredge, L.A., and Nixon, M. 1986. Surficial Geology, Northeastern Manitoba. Geological Survey of Canada, Map 1517A, scale 1:500,000.

Dredge, L.A., and Mott, R.J. 2003. Holocene pollen records and peatland development, northeastern Manitoba. Geographic Phisique et Quarternaire, 57, 7-19. 
Environment Canada 2013. National Climate Data and Information Archive. Churchill Airport, 1953-2012.

Eugster, W., Rouse, W.R., Pielke Sr., R.A., McFadden, J.P., Baldocchi, D.D., Kittel, T.G.F., Chapin III, F.S., Liston, G.E., Vidale, P.L., Vaganov, E., and Chambers, S. 2000. Landatmosphere energy exchange in Arctic tundra and boreal forest: available data and feedbacks to climate. Global Change Biology, 6, 84-115.

Euskirchen, E.S., McGuire, A.D., Kicklighter, D.W., Zhuang, Q., Clein, J.S., Dargaville, R.J., Dye, D.G., Kimball, J.S., McDonald, K.C., Melillo, J.M., Romanovsky, V.E., and Smith, N.V. 2006. Importance of recent shifts in soil thermal dynamics on growing season length, productivity, and carbon sequestration in terrestrial high-latitude ecosystems. Global Change Biology, 12, 731-750.

Fan Z., McGuire, A.D., Turetsky, M.R., Harden, J.W., Waddington, J.M., and Kane, E.S. 2013. The response of soil organic carbon of a rich fen peatland in interior Alaska to projected climate change. Global Change Biology, 19, 604-620.

Falge, E., Baldocchi, D., Olson, R., Anthoni, P., Aubinet, M., Bernhofer, C., Burba, G., Ceulemans, R., Clement, R., Dolman, H., Granier, A., Gross, P., Grunwald, T., Hollinger, D., Jensen, N.O., Katul, G., Keronen, P., Kowalski, A., Lai, C.L., Law, B.E., Meyers, T., Moncrieff, J., Moors, E., Munger, J.W., Pilegaard, K., Rannik, U., Rebmann, C., Suyker, A., Tenhunen, J., Tu, K., Verman, S., and Vesala, T. 2001. Gap filling strategies for defensible annual sums of net ecosystem exchange. Agricultural and Forest Meteorology, 107, 43-69.

Foken, T. 2008. Micro-meteorology. Berlin: Springer. 
Foken, T., Gockede, M., Mauder, M., Mahrt, L., Amiro, B.D., and Munger, J.W. 2004. Post-field quality control, in: Handbook of Micrometeorology. Kluwer Academic Publishers, Dordrecht.

Gagnon, A.S., and Gough, W.A. 2005. Trend and Variability in the Dates of Ice Freeze-up and Breakup over Hudson Bay and James Bay. Arctic 58(4), 370-382

Gorham, E. 1991. Northern Peatlands: Role in the carbon cycle and probable responses to climatic warming. Ecological Applications, 1, 182-195.

Griffis, T.J., Rouse, W.R., and Waddington, J.M. 2000. Interannual variability of net ecosystem $\mathrm{CO}_{2}$ exchange at a subarctic fen. Global Biogeochemical Cycles, 14, 1109-1121.

Groendahl, L., Friborg, T., and Soegaard, H. 2007. Temperature and snow-melt controls on interannual variability in carbon exchange in the high Arctic. Theoretical and Applied Climatology, 88, 111-125.

Hamilton, J.D., Kelly, C.A., Rudd, J.W.M., Hesslein, R.H., and Roulet, N.T. 1994. Flux to the atmosphere of $\mathrm{CH}_{4}$ and $\mathrm{CO}_{2}$ from wetland ponds on the Hudson Bay Lowlands (HBLs). Journal of Geophysical Research, 99, 1495-1510.

Heimann, M., and Reichstein, M. 2008. Terrestrial ecosystem carbon dynamics and climate feedbacks. Nature, 451, 289-292.

Henry, M. 2011. Sea ice trends in Canada. Statistics Canada-EnviroSats, 5, 3-13.

Hinzman, L.D., Bettez, N.D., Bolton, W.R., Chapin, F.S., Dyurgerov, M.B., Fastie, C.L., Griffith, B., Hollister, R.D., Hope, A., et. al. 2005. Evidence and implications of recent climate change in northern Alaska and other arctic regions. Climatic Change, 75, 251298. 
Hinzman, L.D., Goering, D.J., and Kane, D.L. 1998. A distributed thermal model for calculating soil temperature profiles and depth of thaw in permafrost regions. Journal of Geophysical Research: Atmospheres, 103, 28975-28991.

Hochheim, K.P., and Barber, D.G. 2010. Atmospheric forcing of sea ice in Hudson Bay during the fall period, 1980-2005. Journal of Geophysical Research, 115, JC5334.

Hochheim, K.P., Lukovich, J.V., and Barber, D.G. 2011. Atmospheric forcing of sea ice in Hudson Bay during the spring period, 1980-2005. Journal of Marine Systems, 88, 476487.

Joiner, D.W., Lafleur, P.M., McCaughey, J.H., and Bartlett, P.A. 1999. Interannual variability in carbon dioxide exchanges at a boreal wetland in the BOREAS northern study area. Journal of Geophysical Research, 104, 27663-27672.

Kellner, E. 2001. Surface energy fluxes and control of evapotranspiration from a Swedish Sphagnum mire. Agricultural and Forest Meteorology, 110, 101-123.

Lafleur, P.M., and Rouse, W.R. 1988. The influence of surface cover and climate on energy partitioning and evaporation in a subarctic wetland. Boundary-Layer Meteorology, 44, $327-347$.

Lafleur, P.M., Roulet, N.T., and Admiral, S.W. 2001. Annual cycle of $\mathrm{CO}_{2}$ exchange at a bog peatland. Journal of Geophysical Research - Atmospheres, 106, 3071-3081.

Lafleur, P.M., Roulet, N.T., Bubier, J.L., Frolking, S., and Moore, T.R. 2003. Interannual variability in the peatland-atmosphere carbon dioxide exchange at an ombrotrophic bog. Global Biogeochemical Cycles, 17, 1-14.

Lafleur, P.M., Humphreys, E.R., St. Louis, V.L., Myklebust, M.C., Papakyriakou, T., Poissant, L., Barker, J.D., Pilote, M., and Swystun, K.A. 2012. Variation in peak growing season 
net ecosystem production across the Canadian Arctic. Environmental Science and Ecology, 46, 7971-7977.

Lafleur, P.M., McCaughey, J.H., Joiner, D.W., Bartlett, P.A., and Jelinski, D.E. 1997. Seasonal trends in energy, water, and carbon dioxide fluxes at a northern boreal wetland. Journal of Geophysical Research - Atmospheres, 102, 29009-29020.

Lloyd, J., and Taylor, J.A. 1994. On the temperature dependence of soil respiration. Functional Ecology, 8, 315-323.

Lund, M., Lafleur, P.M., Roulet, N.T., Lindroth, A., Christensen, T.R., Aurela, M., Chojnicki, B.H., Flanagan, L.B., Humphreys, E.R., Laurila, T., Oechel, W.C., Olejnik, J., Runne, J., Schubert, P., and Nilsson, M.B. 2010. Variability in exchange of $\mathrm{CO}_{2}$ across 12 northern peatland and tundra sites. Global Change Biology, 16, 2436-2448.

Luo, Y. 2007. Terrestrial carbon-cycle feedback to climate warming. Annual Review of Ecology, Evolution and Systematics, 38, 683-712.

McGuire, A.D., Clein, J.S., Melillo, J.M., Kicklighter, D.W., Meier, R.A., Vorosmarty, C.J., and Serreze, M.C. 2000. Modelling carbon responses of tundra ecosystems to historial and projected climate: sensitivity of pan-Arctic carbon storage to temporal and spatial variation in climate. Global Change Biology, 6, 141-159.

McKane, R.B., Rastetter, E.B., Shaver, G.R., Nadelhoffer, K.J., Giblin, A.E., Laundre, J.A., and Chapin III, F.S. 1997. Climatic effects on tundra carbon storage inferred from experimental data and a model. Ecology, 78, 1170-1187.

Moncrieff, J.B., Clement, R., Finnigan, J., and Meyers, T. 2004. Averaging, detrending and filtering of eddy covariance time series, in: Handbook of Mictometeorology. Kluwer Academic Publishers, Dordrecht. 
Moncrieff, J.B., Malhi, Y., and Leuning, R. 1996. The propagation of errors in long-term measurements of land-atmosphere fluxes of carbon and water. Global Change Biology, 2, 231-240.

Moncrieff, J.B., Massheder, J.M., DeBruin, H., Elbers, J., Friborg, T., Heusinkveld, B., Kabat, P., Scott, S., Soegaard, H., and Verhoef, A. 1997. A system to measure fluxes of momentum, sensible heat, water vapour and carbon dioxide. Journal of Hydrology, 188189, 589-611.

Moore, T.R., and Knowles, R. 1989. The influence of water table levels on methane and carbon dioxide emissions from peatland soils. Canadian Journal of Soil Science, 69, 33-38.

Myneni, R.B., Keeling, C.D., Tucker, C.J., Asrar, G., and Nemani, R.R. 1997. Increased plant growth in the northern high latitudes from 1981-1991. Nature, 386, 698-702.

Nelson, F.E., Shiklomanov, N.I., Mueller, G.R., Hinker, K.M., Walker, D.A., and Bockheim, J.G. 1997. Estimating active-layer thickness over a large region: Kuparuk River Basin, Alaska, USA. Arctic and Alpine Research, 29, 367-378.

Nykanen, H., Alm, J., Lang, K., Silvola, J., and Martikainen, P.J. 1995. Emissions of $\mathrm{CH}_{4}, \mathrm{~N}_{2} \mathrm{O}$ and $\mathrm{CO}_{2}$ from a virgin fen and a fen drained for grassland in Finland. Journal of Biogeography, 22, 351-357.

Oechel, W.C., and Collins, N.J. 1976. Comparative $\mathrm{CO}_{2}$ exchange patterns in mosses from two tundra habitats at Barrow, Alaska. Canadian Journal of Botany, 54, 1355-1369.

Oechel, W.C., Hastings, S.J., Vourlitis, G., Jenkins, M., Riechers, G., and Grulke, N. 1993. Recent change of Arctic tundra ecosystems from a net carbon dioxide sink to a source. Nature, 361, 520-523.

Payette, S., Delwaide, A., Caccianiga, M., and Beauchemin, M. 2004. Accelerated thawing of subarctic peatland permafrost over the last 50 years. Geophysical Research Letters, 31, 14. 
Parmentier, F.J.W., van der Molen, M.K., van Huissteden, J., Karsanaev, S.A., Kononov, A.V., Suzdalov, D.A., Maximov, T.C., and Dolman, A.J. 2011. Longer growing seasons do not appear to increase net carbon uptake in Northeastern Siberian tundra. Journal of Geophysical Research: Biogeosciences, 116, JG1653.

Reichstein, M., Falge, E., Baldocchi, D., Papale, D., Aubinet, M., and Berbigier, P. 2005. On the separation of net ecosystem exchange into assimilation and ecosystem respiration: review and improved algorithm. Global Change Biology, 11, 1424-1439.

Riley, J. 2011. Wetlands of the Hudson Bay Lowlands. Nature Conservancy of Canada and the Ontario Ministry of Natural Resources, Toronto, Ontario, Canada, 156 pp.

Rizzo, R., and Wilken, E. 1992. Assessing the sensitivity of Canada's ecosystems to climatic change. Climatic Change, 21, 35-55.

Roulet, N.T., Lafleur, P.M., Richard, P.J.H., Moore, T.R., Humphreys, E.R., and Bubier, J. 2007. Contemporary carbon balance and late Holocene carbon accumulation in a northern peatland. Global Change Biology, 13, 397-411.

Rouse, W.R., and Bello, R.L. 1985. Impact of Hudson Bay on the energy balance in the Hudson Bay Lowlands and the potential for climatic modification. Atmosphere-Ocean, 23, 375392.

Rouse, W.R. 1993. Northern Climates, in Canada's Cold Environments, H.M. French and O. Slaymaker (eds.), McGill Queens Press Montreal \& Kingston, 340pp.

Rouse, W.R. 2000. The energy and water balance of high-latitude wetlands: control and extrapolation. Global Change Biology, 6, 59-68. 
Rouse, W.R., Bello, R.L., D’Sourza, A., and Griffis, T.J. 2002. The annual carbon budget for fen and forest in a wetland at Arctic treeline. Arctic, 55, 229-237.

Rouse, W.R., Hardill, S.G., and Lafleur, P. 1987. Energy balance in the coastal environment of James Bay and Hudson Bay during the growing season. Journal of Climatology, 7, 165179.

Runkle, B.R.K., Wille, C., Gazovic, M., Wilmking, M., and Kutzbach, L. 2014. The surface energy balance and its drivers in a boreal peatland fen of northwestern Russia. Journal of Hydrology, 511, 359-373.

Schuepp, P.H., Lecrec, M.Y., MacPherson, J.I., and Desjardins, R.L. 1990. Footprint prediction of scalar fluxes from analytical solutions of the diffusion equation. Boundary-Layer Meteorology, 50, 355-373.

Schuur, E.A.G., Bockheim, J., Canadell, J.P., Euskirchen, E., Field, C.B., Goryachkin, S.V., Hagemann, S., Kuhry, P., Lafleur, P.M. et. al. 2008. Vulnerability of permafrost carbon to climate change: implications for the global carbon cycle. BioScience, 58, 701-714.

Serreze, M.C., Walsh, J.E., Chapin III, F.S., Osterkamp, T., Dyurgerov, M., Romanovsky, V., Oechel, W.C., Morison, J., Zhang, T., and Barry, R.G. 2000. Observational evidence of recent change in the northern high-latitude environment. Climatic Change, 45, 159-207.

Shurpali, N.J., Verma, S.B., Kim, J., and Askebauer, T.J. 1995. Carbon dioxide exchange in a peatland ecosystem. Journal of Geophysical Research, 100, 14319-14326.

Silvola, J., Alm, J., Ahlholm, U., Nykanen, H., and Martikainen, P.J. 1996. $\mathrm{CO}_{2}$ fluxes from peat inn boreal mires under varying temperature and moisture conditions. Journal of Ecology, 84, 219-228. 
Smith, L.C., MacDonald, G.M., Velichko, A.A., Beilman, D.W., Borisova, O.K., Kremenetski, K.V., and Sheng, Y. 2004. Siberian peatlands a net carbon sink and global methane source since the early Holocene. Science, 303, 353:356.

Sottocornola, M., and Kiely, G. 2010. Energy fluxes and evaporation mechanisms in an Atlantic blanket bog in southwestern Ireland. Water Resources Research, 46, 1-13.

Stella, G.F., Stein, S., Dixon, T.H., Craymer, M., James, T.S., Mazzotti, S., and Dokka, R.K. 2007. Observation of glacial isostatic adjustment in "stable" North America with GPS. Geophysical Research Letters, 34, 1-6.

Tans, P.P., Fung, I.Y., and Takahashi, T. 1990. Observational constraints on the global atmospheric $\mathrm{CO}_{2}$ budget. Science, 247, 1431-1438.

Waddington, J.M., and Roulet, N.T. 1996. Atmosphere-wetland carbon exchanges: Scale dependency of $\mathrm{CO}_{2}$ and $\mathrm{CH}_{4}$ exchange on the developmental topography of a peatland. Global Biogeochemical Cycles, 10, 233-245.

Webb, E.K., Pearman, G.I., and Leuning, R. 1980. Correction of flux measurements for density effects due to heat and water vapour transfer. Quarterly Journal of Royal Meteorological Society, 106, 85-100.

Wilczak, J.M., Oncley, S.P., and Stage, S.A. 2001. Sonic anemometer tilt correction algorithms. Boundary-Layer Meteorology, 99, 127-150.

Zimov, S.A., Davidov, S.P., Zimova, G.M., Davidova, A.I., Chapin III, F.S., Chapin, M.C., and Reynolds, J.F. 1999. Contribution of disturbance to increasing seasonal amplitude of atmospheric $\mathrm{CO}_{2}$. Science, 284, 1973-1976. 
Zimov, S.A., Davydov, S.P., Zimova, G.M., Davydova, A.I., Schuur, E.A.G., Dutta, K., and Chapin III, F.S. 2006. Permafrost carbon: Stock and decomposability of a globally significant carbon pool. Geophysical Research Letters, 33, L20502. 


\section{Figure Captions}

Fig. 1. Map of tower location and surrounding water bodies. Small ponds have been omitted. Inset: Location of Churchill Manitoba near the northern limit of the Hudson Bay Lowlands (black).

Fig. 2. Cumulative precipitation and evaporation rates $(\mathrm{mm})$ over the study period.

Fig. 3. Mean monthly diurnal temperature curves for onshore and offshore wind regimes.

Fig. 4. Mean monthly energy balance for onshore and offshore wind regimes, as derived from mean monthly 30-minute daytime fluxes. September values are calculated until September $18^{\text {th }}$. Note the different axis scale for $\mathrm{Q}_{\mathrm{G}}$. Error bars represent standard error.

Fig. 5. Seasonal daily average NEE for data from all wind directions.

Fig. 6. (a) Binned light response curve for GPP for onshore and offshore wind regimes ( $>0.05$ ). (b) Temperature response over binned light levels for onshore and offshore wind regimes $(\mathrm{p}<0.001)$.

Fig. 7. (a) Daytime GPP and R (Lloyd and Taylor (1974) model) curves for binned air temperatures for onshore and offshore regimes. ER estimates are based on the same model for both wind directions due to the same model that was used. (b) Daytime NEE curves for binned air temperatures for onshore and offshore wind regimes.

Fig. 8. Changes in the proportion of onshore and offshore wind regime frequencies for June from 1953 to $2012 .(p=0.06)$. 


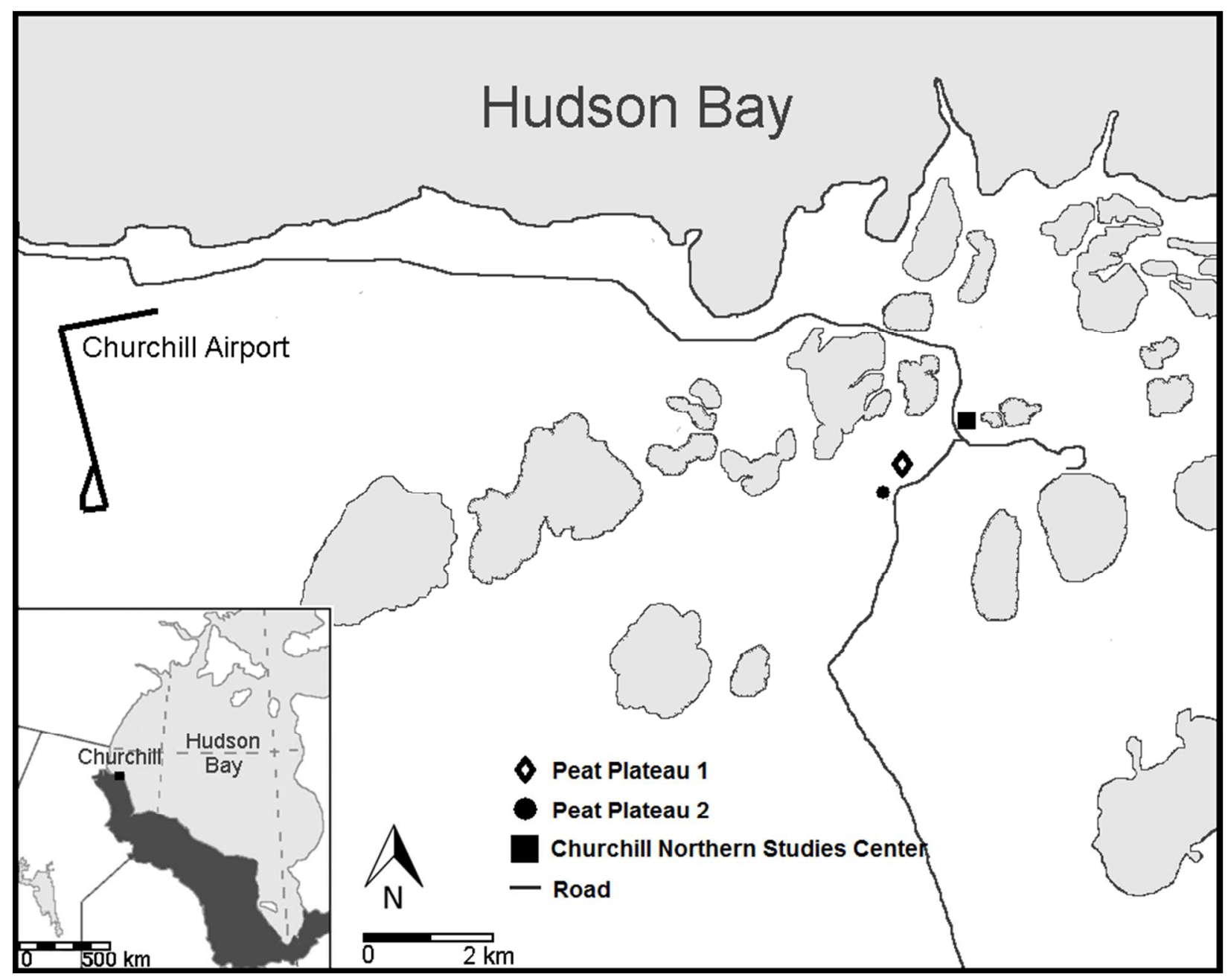

Fig. 1. Map of tower location and surrounding water bodies. Small ponds have been omitted. Inset: Location of Churchill Manitoba near the northern limit of the Hudson Bay Lowlands (black). 


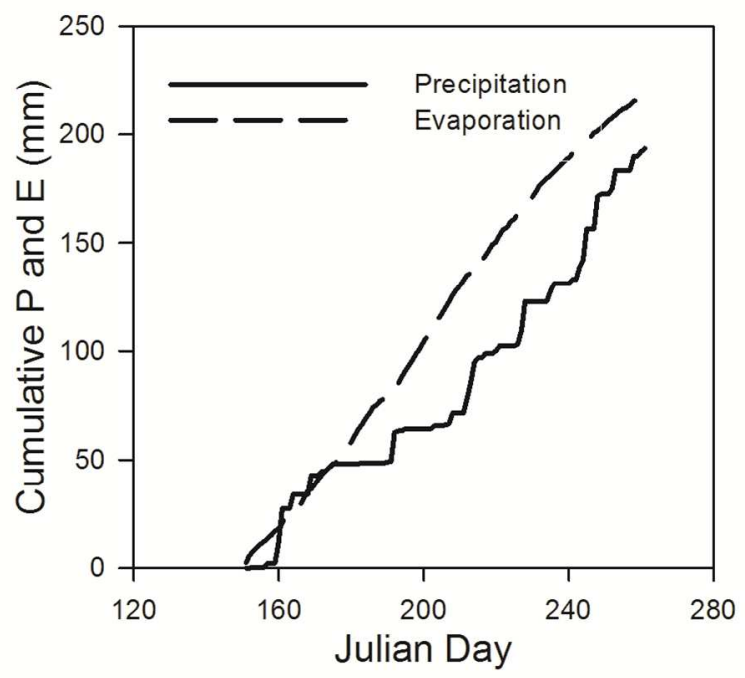

Fig. 2. Cumulative precipitation and evaporation rates $(\mathrm{mm})$ over the study period. 


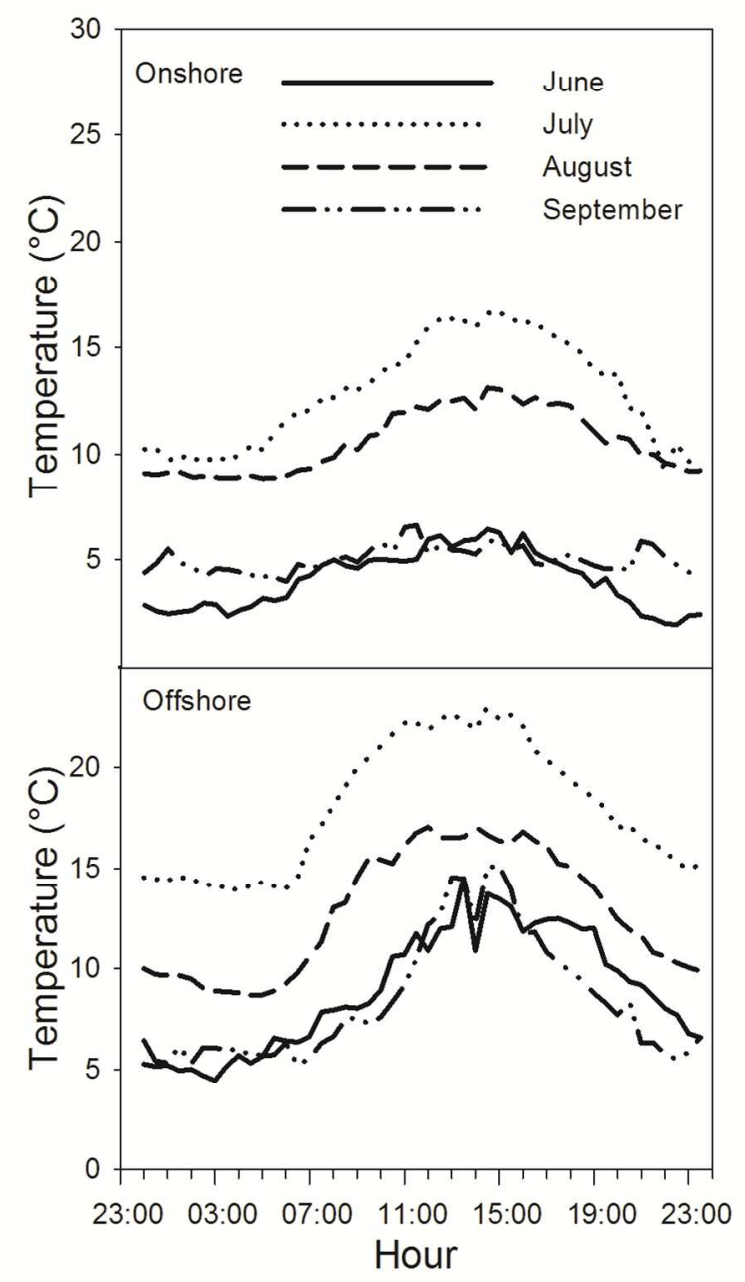

Fig. 3. Mean monthly diurnal temperature curves for onshore and offshore wind regimes. 


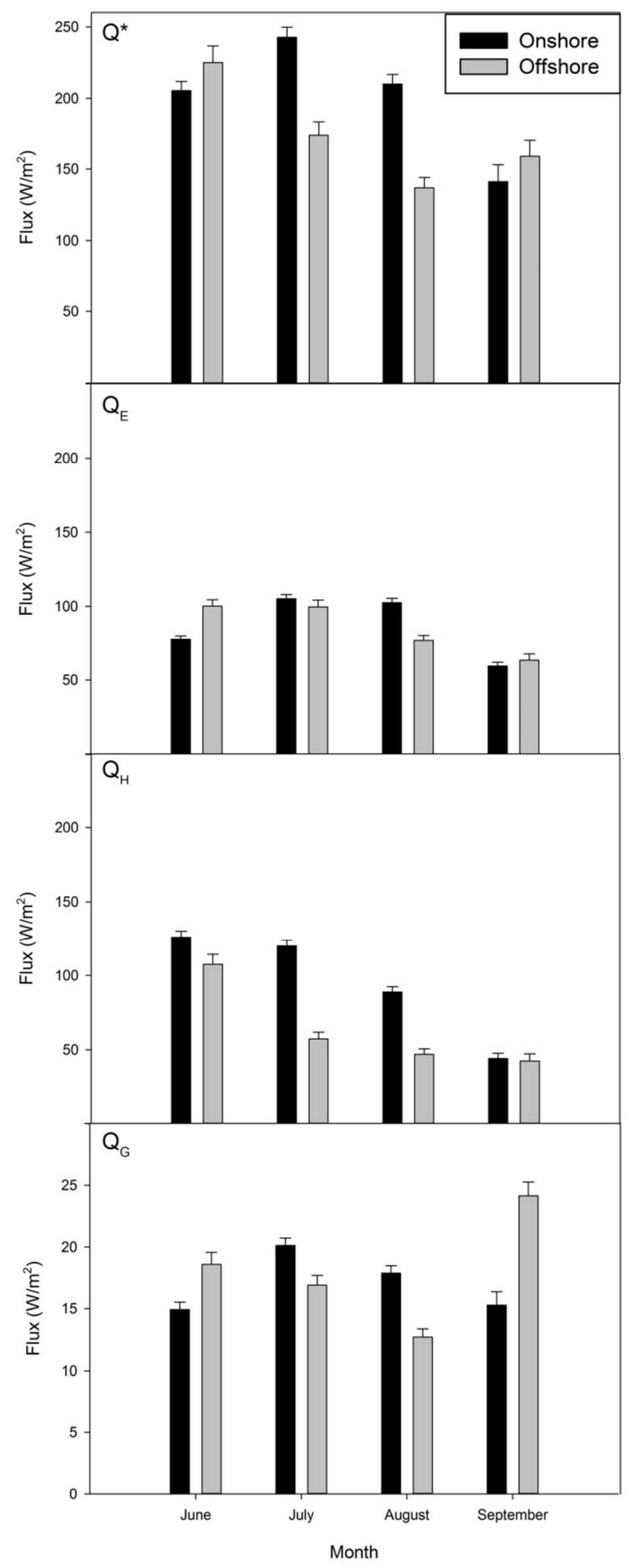

Fig. 4. Mean monthly energy balance for onshore and offshore wind regimes, as derived from mean monthly 30minute daytime fluxes. September values are calculated until September $18^{\text {th }}$. Note the different axis scale for $\mathrm{Q}_{\mathrm{G}}$. Error bars represent standard error. 


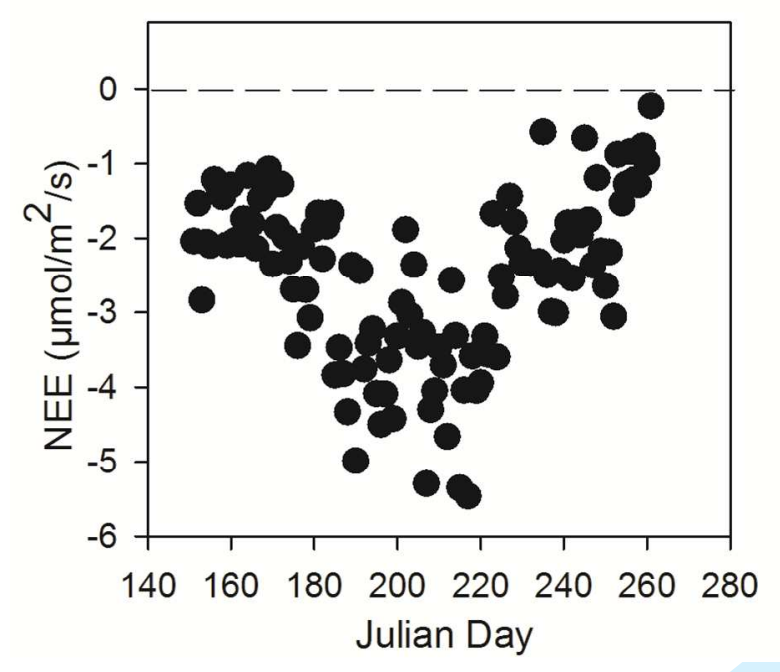

Fig. 5. Seasonal daily average NEE for data from all wind directions. 


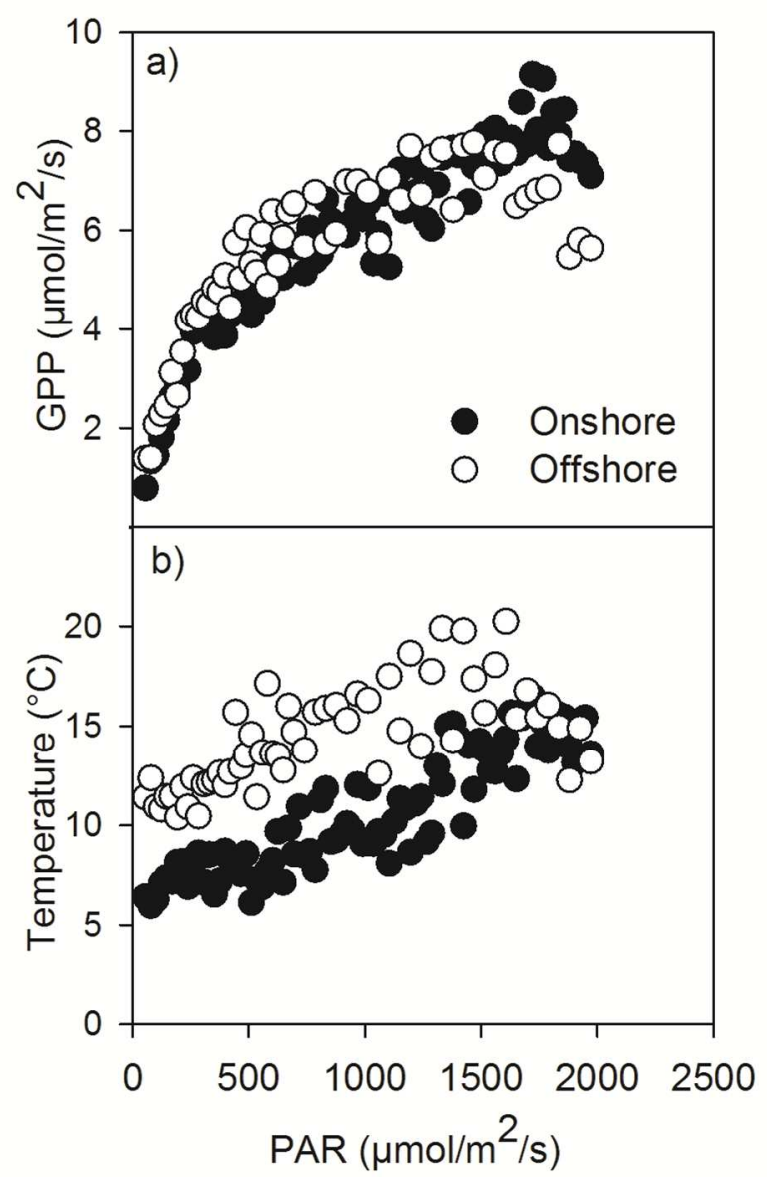

Fig. 6. (a) Binned light response curve for GPP for onshore and offshore wind regimes ( $p>0.05$ ). (b) Temperature response over binned light levels for onshore and offshore wind regimes $(p<0.001)$. 


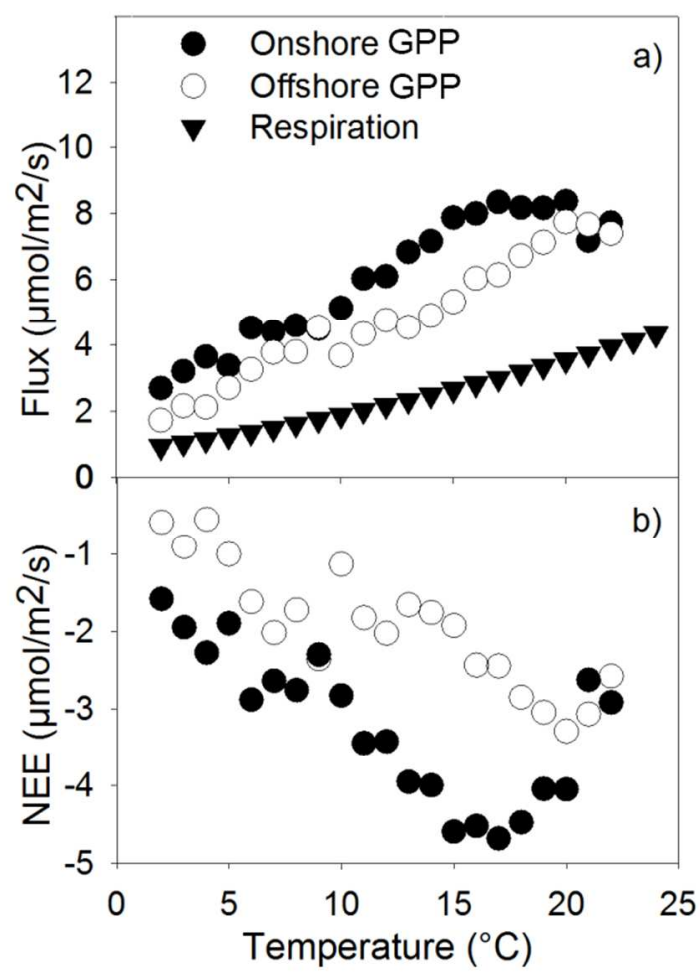

Fig. 7. (a) Daytime GPP and R (Lloyd and Taylor (1974) model) curves for binned air temperatures for onshore and offshore regimes. ER estimates are based on the same model for both wind directions due to the same model that was used. (b) Daytime NEE curves for binned air temperatures for onshore and offshore wind regimes. 


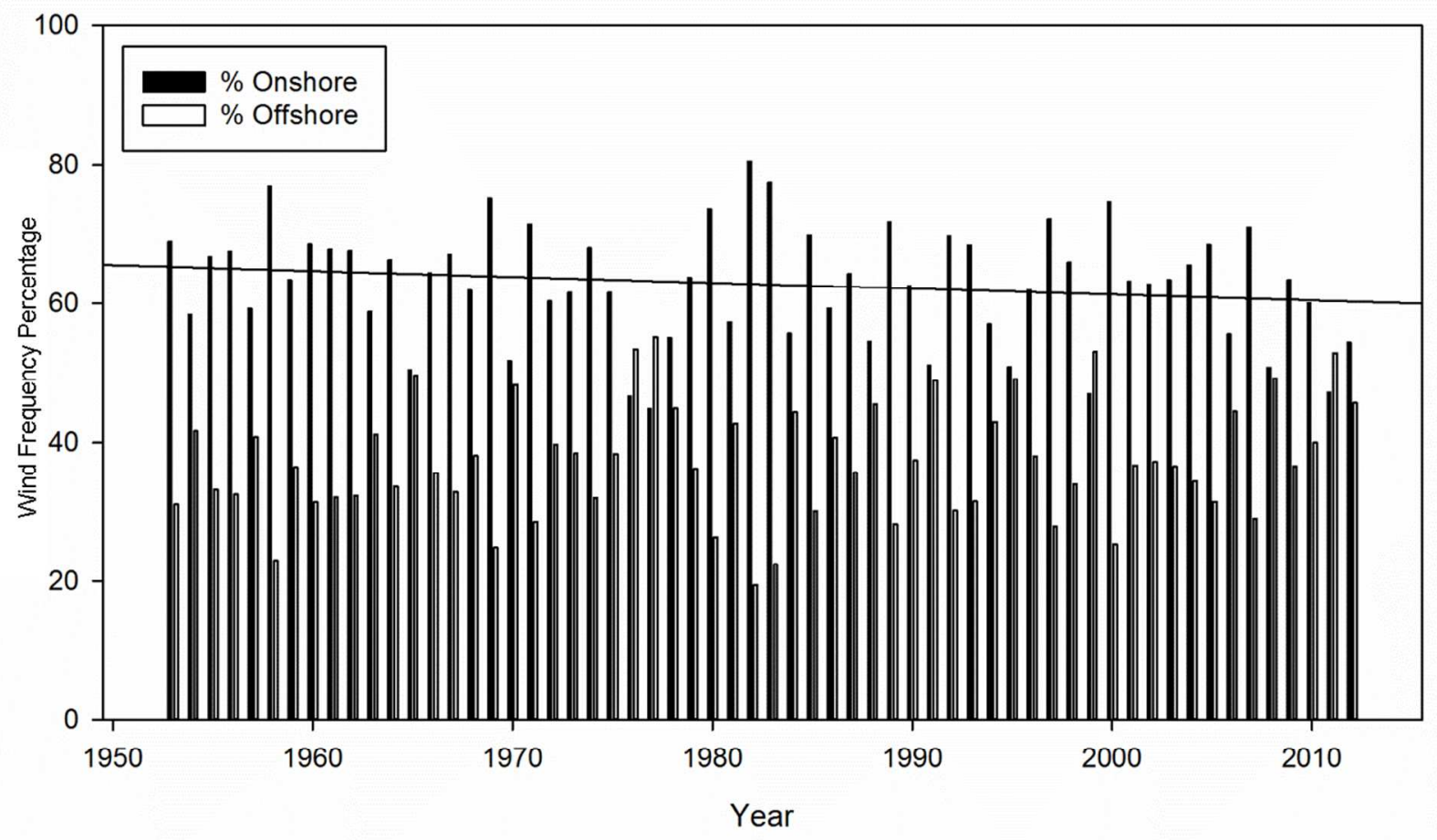

Fig. 8. Changes in the proportion of onshore and offshore wind regime frequencies for June from 1953 to 2012. $(\mathrm{p}=0.06)$. 
Table 1. Percent plant cover surrounding the EC tower within $100 \mathrm{~m}$ radius. Sampling methods are based on $50 \mathrm{~cm}$ x $50 \mathrm{~cm}$ quadrat sampling at $2 \mathrm{~m}$ intervals in 16 compass directions.

\begin{tabular}{|c|l|}
\hline Plant Cover & Percent Cover \\
\hline Understory & \\
\hline Vascular & 47.8 \\
\hline Lichen & 25.4 \\
\hline Moss & 23.2 \\
\hline Pond & 1.0 \\
\hline Rock & 2.7 \\
\hline Overstory & \\
\hline Cloudberry & 13.6 \\
\hline Birch & 2.1 \\
\hline Willow & 4.0 \\
\hline Evergreen & 1.9 \\
\hline
\end{tabular}


Table 2. Relative influence for four dominant plant covers (vascular, lichen, moss, cloudberry) computed for onshore and offshore wind directions. T-tests were performed, and a difference in magnitude is shown. Relative influence was computed using a weighted footprint model after Schuepp et al., (1990). (* $\mathrm{p}<0.05 ; * * \mathrm{p}<0.01, * * *$ $\mathrm{p}<0.001)$.

\begin{tabular}{|l|r|r|r|r|}
\hline & & \multicolumn{2}{|c|}{ Relative Influence } & $\begin{array}{l}\text { Difference } \\
\text { Magnitude }\end{array}$ \\
\hline & $\begin{array}{l}\text { Statistical } \\
\text { Significance }\end{array}$ & Onshore & Offshore & \\
\hline $\begin{array}{l}\text { Understory } \\
\text { Vascular }\end{array}$ & $*$ & 33.12 & 32.51 & 1.02 \\
\hline $\begin{array}{l}\text { \%nderstory } \\
\begin{array}{l}\text { Lichen } \\
\%\end{array}\end{array}$ & $*$ & 22.90 & 21.94 & 1.04 \\
\hline $\begin{array}{l}\text { Understory } \\
\text { Moss }\end{array}$ & $* * *$ & 17.85 & 13.54 & 1.32 \\
\hline $\begin{array}{l}\text { \% Overstory } \\
\text { Cloudberry }\end{array}$ & $* * *$ & 12.73 & 11.70 & 1.09 \\
\hline
\end{tabular}


Table 3. Monthly precipitation $(\mathrm{mm})$ and temperature $\left({ }^{\circ} \mathrm{C}\right)$ for the study year of 2007 and historical average (HA) values. Bracketed terms show one standard deviation.

\begin{tabular}{|c|c|c|c|c|c|c|c|c|}
\hline & \multicolumn{2}{|c|}{ June } & \multicolumn{2}{c|}{ July } & \multicolumn{2}{c|}{ August } & \multicolumn{2}{c|}{$\begin{array}{c}\text { September (until } \\
\left.18^{\text {th }}\right)\end{array}$} \\
\hline & $\begin{array}{c}200 \\
7\end{array}$ & HA & 2007 & HA & $\begin{array}{c}200 \\
7\end{array}$ & HA & 2007 & HA \\
\hline $\begin{array}{c}\text { Precipitation } \\
(\mathrm{mm})\end{array}$ & 48.2 & 44.3 & 2 & 56 & 44.4 & 68.3 & 70.6 & 63.4 \\
\hline $\mathrm{T}\left({ }^{\circ} \mathrm{C}\right)$ & 5.9 & $\begin{array}{c}6.6 \\
(2.1)\end{array}$ & 15.4 & $\begin{array}{c}12 \\
(1.7)\end{array}$ & 12 & $\begin{array}{c}11.7 \\
(1.5)\end{array}$ & 5.4 & \\
\hline
\end{tabular}


Table 4. Energy balance components as proportions of net available energy for onshore (ON) and offshore (OFF) wind regimes for the four study months, as derived from 30 -minute daytime fluxes. SS-statistical significance. *

$$
\mathrm{P}<0.05 ; * * \mathrm{P}<0.01 ; * * * \mathrm{P}<0.001 \text {. }
$$

\begin{tabular}{|l|c|c|c|c|c|c|c|c|c|}
\hline & \multicolumn{4}{|c|}{$\mathbf{Q}_{\mathrm{E}} / \mathbf{Q}^{*}$} & \multicolumn{4}{c|}{$\mathbf{Q}_{\mathbf{H}} / \mathbf{Q}^{*}$} & \multicolumn{4}{c|}{$\mathbf{Q}_{\mathbf{G}} / \mathbf{Q}^{*}$} \\
\cline { 2 - 12 } & ON & OFF & SS & ON & OFF & SS & ON & OFF & SS \\
\cline { 2 - 11 } June & 0.46 & 0.41 & - & 0.61 & 0.44 & $* *$ & 0.05 & 0.05 & - \\
July & 0.49 & 0.58 & - & 0.45 & 0.23 & $* * *$ & 0.09 & 0.17 & $* *$ \\
August & 0.61 & 0.63 & - & 0.28 & 0.11 & $* *$ & 0.10 & 0.13 & $*$ \\
September & 0.69 & 0.40 & - & 0.11 & 0.38 & $*$ & 0.12 & 0.26 & - \\
Season & 0.46 & 0.53 & - & 0.44 & 0.26 & $* * *$ & 0.08 & 0.14 & $* *$ \\
\hline
\end{tabular}


Table 5. (a) Monthly and seasonal flux means and flux normalized to PAR for onshore and offshore wind regimes, as derived from 30-minute daytime fluxes. (b) Ratios of offshore to onshore $(\mathrm{OFF} / \mathrm{ON})$ represent $\%$ difference with associated statistical test. SS-statistical significance. ${ }^{*} \mathrm{P}<0.05 ; * * \mathrm{P}<0.01 ; * * * \mathrm{P}<0.001$.

\begin{tabular}{|c|c|c|c|c|c|c|c|c|c|c|c|c|c|c|}
\hline \multirow[t]{2}{*}{ (a) } & \multicolumn{2}{|c|}{$\begin{array}{c}\text { GPP } \\
\left(\mu \mathrm{mol} / \mathrm{m}^{2} / \mathrm{s}\right)\end{array}$} & \multicolumn{2}{|c|}{$\begin{array}{c}\text { ER } \\
\left(\mu \mathrm{mol} / \mathrm{m}^{2} / \mathrm{s}\right) \\
\end{array}$} & \multicolumn{2}{|c|}{$\begin{array}{c}\text { NEE } \\
\left(\mu \mathrm{mol} / \mathrm{m}^{2} / \mathrm{s}\right)\end{array}$} & \multicolumn{2}{|c|}{$\begin{array}{c}\mathrm{T} \\
\left({ }^{\circ} \mathrm{C}\right) \\
\end{array}$} & \multicolumn{2}{|c|}{$\begin{array}{c}\text { GPP/PAR } \\
\left(\mu \mathrm{mol} \mathrm{CO} \mathrm{CO}_{2} /\right. \\
\mu \mathrm{mol} \text { photons })\end{array}$} & \multicolumn{2}{|c|}{ 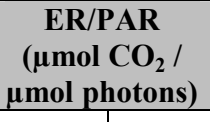 } & \multicolumn{2}{|c|}{ ER/GPP } \\
\hline & ON & OFF & ON & OFF & ON & OFF & ON & OFF & ON & OFF & $\mathrm{ON}$ & OFF & $\mathrm{ON}$ & OFF \\
\hline June & $\begin{array}{c}3.69 \\
\pm 0.07\end{array}$ & $\begin{array}{c}4.17 \\
\pm 0.10\end{array}$ & $\begin{array}{c}1.53 \\
\pm 0.02\end{array}$ & $\begin{array}{c}2.21 \\
\pm 0.04\end{array}$ & $\begin{array}{l}-2.16 \\
\pm 0.07\end{array}$ & $\begin{array}{l}-1.91 \\
\pm 0.09\end{array}$ & 4.93 & 9.70 & 0.73 & 0.80 & 0.46 & 0.57 & 0.53 & 0.63 \\
\hline July & $\begin{array}{c}7.29 \\
\pm 0.11\end{array}$ & $\begin{array}{c}7.02 \\
\pm 0.19\end{array}$ & $\begin{array}{c}3.31 \\
\pm 0.04\end{array}$ & $\begin{array}{c}4.31 \\
\pm 0.06\end{array}$ & $\begin{array}{l}-3.95 \\
\pm 0.10\end{array}$ & $\begin{array}{l}-2.49 \\
\pm 0.16\end{array}$ & 14.39 & 19.46 & 1.28 & 1.69 & 0.83 & 1.58 & 0.55 & 0.78 \\
\hline August & $\begin{array}{c}6.35 \\
\pm 0.11\end{array}$ & $\begin{array}{c}5.83 \\
\pm 0.14\end{array}$ & $\begin{array}{c}2.82 \\
\pm 0.02\end{array}$ & $\begin{array}{c}3.40 \\
\pm 0.05\end{array}$ & $\begin{array}{l}-3.54 \\
\pm 0.11\end{array}$ & $\begin{array}{l}-2.47 \\
\pm 0.14\end{array}$ & 11.66 & 14.59 & 1.20 & 1.58 & 0.74 & 1.33 & 0.56 & 0.93 \\
\hline September & $\begin{array}{c}3.58 \\
\pm 0.11\end{array}$ & $\begin{array}{c}4.17 \\
\pm 0.18\end{array}$ & $\begin{array}{c}1.75 \\
\pm 0.03\end{array}$ & $\begin{array}{c}2.48 \\
\pm 0.06\end{array}$ & $\begin{array}{l}-1.80 \\
\pm 0.10\end{array}$ & $\begin{array}{l}-1.55 \\
\pm 0.16\end{array}$ & 5.28 & 9.58 & 1.15 & 1.19 & 0.82 & 1.15 & 0.71 & 1.28 \\
\hline Season & $\begin{array}{c}5.43 \\
\pm 0.06 \\
\end{array}$ & $\begin{array}{c}5.45 \\
\pm 0.09 \\
\end{array}$ & $\begin{array}{c}2.42 \\
\pm 0.02 \\
\end{array}$ & $\begin{array}{c}3.19 \\
\pm 0.04 \\
\end{array}$ & $\begin{array}{l}-3.00 \\
\pm 0.05\end{array}$ & $\begin{array}{l}-2.20 \\
\pm 0.07 \\
\end{array}$ & 9.52 & 13.67 & 1.07 & 1.35 & 0.68 & 1.17 & 0.60 & 0.99 \\
\hline
\end{tabular}

\begin{tabular}{|c|c|c|c|c|c|c|c|c|c|c|c|c|c|c|}
\hline \multirow[t]{2}{*}{ (b) } & \multicolumn{2}{|c|}{ GPP } & \multicolumn{2}{|c|}{ ER } & \multicolumn{2}{|c|}{ NEE } & \multicolumn{2}{|c|}{$\begin{array}{c}\mathrm{T} \\
\left({ }^{\circ} \mathrm{C}\right)\end{array}$} & \multicolumn{2}{|c|}{ GPP/PAR } & \multicolumn{2}{|c|}{ ER/PAR } & \multicolumn{2}{|c|}{ ER/GPP } \\
\hline & $\begin{array}{l}\text { OFF/ } \\
\text { ON } \\
\text { Mean }\end{array}$ & SS & $\begin{array}{l}\text { OFF/ } \\
\text { ON } \\
\text { Mean }\end{array}$ & SS & $\begin{array}{l}\text { OFF/ } \\
\text { ON } \\
\text { Mean }\end{array}$ & SS & $\begin{array}{l}{ }^{\circ} \mathrm{C} \\
\text { higher } \\
\text { for OFF }\end{array}$ & SS & $\begin{array}{l}\text { OFF/ } \\
\text { ON } \\
\text { Mean }\end{array}$ & SS & $\begin{array}{l}\text { OFF/ } \\
\text { ON } \\
\text { Mean }\end{array}$ & SS & $\begin{array}{l}\mathrm{OFF} / \\
\mathrm{ON} \\
\text { Mean }\end{array}$ & SS \\
\hline June & 1.13 & $* * *$ & 1.45 & $* * *$ & 0.88 & * & 4.77 & $* * *$ & 1.09 & - & 1.26 & $* *$ & 1.18 & $* * *$ \\
\hline July & 0.96 & - & 1.30 & $* * *$ & 0.63 & $* * *$ & 5.07 & $* * *$ & 1.32 & $* * *$ & 1.91 & $* * *$ & 1.43 & $* * *$ \\
\hline August & 0.92 & $* *$ & 1.20 & $* * *$ & 0.70 & *** & 2.93 & $* * *$ & 1.31 & $* * *$ & 1.80 & $* * *$ & 1.65 & $* *$ \\
\hline September & 1.16 & - & 1.42 & $* * *$ & 0.86 & - & 4.30 & $* * *$ & 1.04 & - & 1.40 & $* * *$ & 1.81 & $* *$ \\
\hline Season & 1.00 & - & 1.32 & $* * *$ & 0.73 & $* * *$ & 4.15 & $* * *$ & 1.26 & $* * *$ & 1.71 & $* * *$ & 1.67 & $* * *$ \\
\hline
\end{tabular}

